\title{
Chromite-PGM Mineralization in the Lherzolite Mantle Tectonite of the Kraka Ophiolite Complex (Southern Urals, Russia)
}

\author{
Giorgio Garuti $^{1}$, Evgenii V. Pushkarev ${ }^{2, *}$, , Irina A. Gottman ${ }^{2}$ and Federica Zaccarini ${ }^{1}$ \\ 1 Department of Applied Geosciences and Geophysics, University of Leoben, Peter Tunner Str. 5, \\ 8700 Leoben, Austria; giorgio.garuti1945@gmail.com (G.G.); Federica.Zaccarini@unileoben.ac.at (F.Z.) \\ 2 Institute of Geology and Geochemistry, Ural Branch of the Russian Academy of Science, Vonsovskogo Str. 15, \\ 620110 Yekaterinburg, Russia; gottman@igg.uran.ru \\ * Correspondence: pushkarev.1958@mail.ru; Tel.: +7-912-604-3802
}

Citation: Garuti, G.; Pushkarev, E.V.; Gottman, I.A.; Zaccarini, F.

Chromite-PGM Mineralization in the Lherzolite Mantle Tectonite of the Kraka Ophiolite Complex (Southern Urals, Russia). Minerals 2021, 11, 1287. https://doi.org/10.3390/ $\min 11111287$

Academic Editor:

Rubén Díez-Fernández

Received: 1 October 2021

Accepted: 16 November 2021

Published: 19 November 2021

Publisher's Note: MDPI stays neutral with regard to jurisdictional claims in published maps and institutional affiliations.

Copyright: (c) 2021 by the authors. Licensee MDPI, Basel, Switzerland. This article is an open access article distributed under the terms and conditions of the Creative Commons Attribution (CC BY) license (https:// creativecommons.org/licenses/by/ $4.0 /)$.

\begin{abstract}
The mantle tectonite of the Kraka ophiolite contains several chromite deposits. Two of them consisting of high-Cr podiform chromitite- the Bolshoi Bashart located within harzburgite of the upper mantle transition zone and Prospect 33 located in the deep lherzolitic mantle-have been investigated. Both deposits are enveloped in dunite, and were formed by reaction between the mantle protolith and high-Mg, anhydrous magma, enriched in $\mathrm{Al}_{2} \mathrm{O}_{3}, \mathrm{TiO}_{2}$, and $\mathrm{Na}_{2} \mathrm{O}$ compared with boninite. The PGE mineralization is very poor $(<100 \mathrm{ppb})$ in both deposits. Laurite $\left(\mathrm{RuS}_{2}\right)$ is the most common PGM inclusion in chromite, although it is accompanied by erlichmanite $\left(\mathrm{OsS}_{2}\right)$ and $(\mathrm{Ir}, \mathrm{Ni})$ sulfides in Prospect 33. Precipitation of PGM occurred at sulfur fugacity and temperatures of $\log f \mathrm{~S}_{2}=(-3.0), 1300-1100{ }^{\circ} \mathrm{C}$ in Bolshoi Bashart, and $\log f \mathrm{~S} 2=(-3.0 /+1.0), 1100-800{ }^{\circ} \mathrm{C}$ in Prospect 33, respectively. The paucity of chromite-PGM mineralization compared with giant chromite deposits in the mantle tectonite in supra-subduction zones (SSZ) of the Urals (Ray-Iz, Kempirsai) is ascribed to the peculiar petrologic nature (low depleted lherzolite) and geodynamic setting (rifted continental margin?) of the Kraka ophiolite, which did not enable drainage of the upper mantle with a large volume of mafic magma.
\end{abstract}

Keywords: chromitite; platinum group minerals; low depleted lherzolite; Kraka ophiolite complex; Southern Urals; Russia

\section{Introduction}

Podiform chromitite associated with ophiolites ranks second among sources of chromite for industrial use, after the Bushveld-type stratiform deposits. The Ural Mountains (Figure 1A) have long been known as an emblematic chromite and platinum group element (Cr-PGE) metallogenic province, extending more than $2000 \mathrm{~km}$ along the $60^{\circ} \mathrm{E}$ meridian, from $50^{\circ}$ to $70^{\circ}$ latitude $\mathrm{N}$ [1]. The chromite associates with ophiolites, whereas the PGE (PGE = Os, Ir, Ru, Rh, Pt, Pd), mainly platinum, occur in placers derived from the erosion of dunite/chromitite bodies at the cores of zoned intrusions of Ural-Alaskan type.

The chromite deposits include refractory-grade (high-Al) and metallurgical-grade (high-Cr) ore types, either hosted in distinct petrologic units of the ophiolite, mantle tectonite, and supra-Moho cumulates, or located at different levels of the mantle tectonite stratigraphy [2-15]. Ophiolites have been divided by many authors in two types: (1) lherzolite type (LOT), which are the products of low degrees of melting of less-depleted subcontinental lithospheric mantle, and (2) harzburgite type (HOT), which represent the products of high degrees of melting of depleted, harzburgitic mantle [11-17]. According to most authors, economic chromite deposits occur preferentially in the mantle sections of harzburgite-ophiolite-type complexes (HOT) ([18,19] and references therein). They are characterized by high-Cr and low-Ti composition, and are interpreted as the results of 
metasomatic reactions between residual mantle and percolating boninite magma [20] in supra-subduction-zones (SSZ). Rollinson attributed the coexistence of Al-rich and Cr-rich chromitites within the same mantle section of the Oman ophiolite to successive intrusions of mid-ocean ridge basalt (MORB) and boninitic magmas. The variations in melt compositions were produced by a melt-rock reaction, whereby a basaltic melt has reacted with harzburgitic mantle to yield successively more Cr-rich melts, without changes in the tectonic environment to explain the different chromite types [21].

Several studies have emphasized that the high-Cr deposits of the Urals contain geochemical anomalies of PGE that are accounted for by minute platinum group mineral (PGM) inclusions in the chromite [10,12,13].

Modal and geochemical prevalences of the refractory Os, Ir, and Ru (IPGE) over the low-melting $\mathrm{Rh}, \mathrm{Pt}$, and Pd (PPGE) result in the typical negative slope of chondritenormalized PGE patterns that distinguish the PGE mineralization in ophiolites from the Pt-specialized mineralization of Ural-Alaskan type [22-29]. There are, however, significant differences in total PGE content and PGM mineralogy between ophiolitic chromite deposits, showing total PGE concentrations up to more than 1 ppm or low PGE contents not exceeding a few hundred ppb. The reasons for this discrepancy have been matter of debate and are not completely understood, although they are seemingly related to the different thermodynamic conditions of the chromite forming system.

In this contribution we present the unusual occurrence of high-Cr, low-Ti podiform chromitite in the mantle tectonite of the lherzolite-ophiolite-type (LOT) of Kraka (Southern Urals, Russia). The chromitites in the deposits of Bolshoi Bashart (BB) and Prospect 33 have been objects of exploitation since the middle of the last century [4]. They have to be distinguished from veinlets of high-Fe chromitite recently described in the wehrliteclinopyroxenite cumulates of the Middle Kraka massif, which were found to contain scattered Pt-PGM [29], but are not big enough for ore deposits. The deposits investigated in this work occur in the mantle-tectonite unit of the Kraka ophiolite: one (Bolshoi Bashart) occurs inside massive harzburgite of the upper mantle transition-zone; the other (Prospect 33) is at depth in the lherzolite mantle unit [30,31]. The mineral chemistry of chromite, and the compositions of accessory silicates and PGM inclusions have been studied and compared with analogous deposits of the Urals in order to identify the metallogenic processes that led to the formation of high-Cr chromitite in a poorly depleted mantle slab.

\section{Analytical Techniques}

Chromite, silicates, and PGM were analyzed by the Superprobe Jeol JXA 8200 electron microprobe in use to the Eugen F. Stumpfl Laboratory, University of Leoben, Austria. Further data were provided by the JSM6390LV SEM, Jeol, and INCA Energy 450 Xmax 80 EDS, Oxford Instruments installed at the Geoanalytic Center of the Institute of Geology and Geochemistry, Ural Branch, Russian Academy of Sciences, Ekaterinburg, Russia. Back scattered electron (BSE) images were obtained using the same instruments.

The electron microprobe analyses of chromite and silicates were carried out in WDSmode, with $15 \mathrm{kV}$ accelerating voltage and $10 \mathrm{nA}$ beam current. The analyses of $\mathrm{Na}, \mathrm{Mg}$, $\mathrm{K}, \mathrm{Al}, \mathrm{Si}, \mathrm{Ca}, \mathrm{Ti}, \mathrm{V}, \mathrm{Cr}, \mathrm{Zn}, \mathrm{Mn}, \mathrm{Fe}$, and $\mathrm{Ni}$ were performed on $\mathrm{K} \alpha$ lines, and calibrated on the standards: chromite, rhodonite, ilmenite, albite, pentlandite, wollastonite, kaersutite, sphalerite, and metallic vanadium. The diffracting crystals were: TAP for $\mathrm{Na}, \mathrm{Mg}$, and $\mathrm{Al}$; PETJ for K, Si, and Ca; and LIFH for Ti, V, Cr, Zn, Mn, Fe, and Ni. Counting times of 20 and $10 \mathrm{~s}$ were used for peak and backgrounds, in the analysis of major elements. They were increased to 40 and 20 for trace elements, such $\mathrm{Ca}, \mathrm{Ni}$, and $\mathrm{Mn}$ in olivine. The detection limits (ppm) calculated by the microprobe software are: $\mathrm{Na}(150), \mathrm{Mg}(100), \mathrm{K}(80), \mathrm{Al}(150)$, Si (250), Ca (50), Ti (250), V (150), Cr (200), Zn (200), Mn (100), Fe (100), and Ni (150). The amount of $\mathrm{Fe}^{3+}$ in chromite was calculated assuming the ideal spinel stoichiometry.

The PGM and other accessory phases were preliminary located by scanning the polished sections under reflected light and electron microscopes, then analyzed in situ by electron microprobe. Small grains $(<5 \mu \mathrm{m})$ were qualitatively identified by EDS analysis. 
Larger minerals were quantitatively analyzed in the WDS mode, at $20 \mathrm{kV}$ accelerating voltage and $10 \mathrm{nA}$ beam current, allowing a beam diameter of about $1 \mu \mathrm{m}$. The peak and background counting times were $15 \mathrm{~s}$ and $5 \mathrm{~s}$, respectively. The $\mathrm{K} \alpha$ lines were used for $\mathrm{S}$, As, $\mathrm{Fe}, \mathrm{Ni}$, and $\mathrm{Cu} ; \mathrm{L} \alpha$ for $\mathrm{Ir}, \mathrm{Ru}, \mathrm{Rh}, \mathrm{Pd}$, and $\mathrm{Pt}$, and $\mathrm{M} \alpha$ for Os. Pure metals standards were used for $\mathrm{Ru}, \mathrm{Rh}, \mathrm{Pd}, \mathrm{Os}$, Ir, Pt, synthetic NiS, natural pyrite, chalcopyrite and niccolite for $\mathrm{Ni}, \mathrm{Fe}, \mathrm{Cu}, \mathrm{S}$, and As. The diffracting crystals were: PETJ for $\mathrm{S}$ and P; PETH for Ru, Os, and $\mathrm{Rh}$; $\mathrm{LIFH}$ for $\mathrm{Fe}, \mathrm{Ni}, \mathrm{Cu}$, Ir, and Pt; and TAP for As. Automatic corrections were performed for interferences involving Ru-Rh and Rh-Pd. Five samples of massive chromitite from the Bolshoi Bashart mine were analyzed for PGE by Inductively Coupled Plasma-Mass Spectrometry (ICP-MS) after Ni sulfide pre-concentration.

\section{Geological Setting}

\subsection{Regional Geological Background}

The Cr-PGE metallogenic province of the Urals was formed by a sequence of magmatic events marking the geodynamic evolution of an ocean settled between the European and Siberia-Kazakh continents, in pre-Palaeozoic times. Following continental rifting and ocean opening, convergent geodynamics produced a sequence of east-dipping intra-oceanic subduction zones that culminated in final plate collision; thereby, large fragments of the sub-oceanic lithosphere (the ophiolites) and island arc complexes (Ural-Alaskan-type zoned intrusions) were incorporated in various lithostratigraphic units of the Ural Orogenic Belt.

Following to the classification proposed by Dilek and Furnes, the Uralian ophiolites can be grouped as: (i) subduction-unrelated ophiolites formed in nascent spreading centers at mid oceanic ridges (MOR), back-arc basins (BA), and rifted continental margins (CM); or (ii) subduction-related ophiolites evolved or emplaced SSZ, and volcanic arc (VA) settings [32,33].

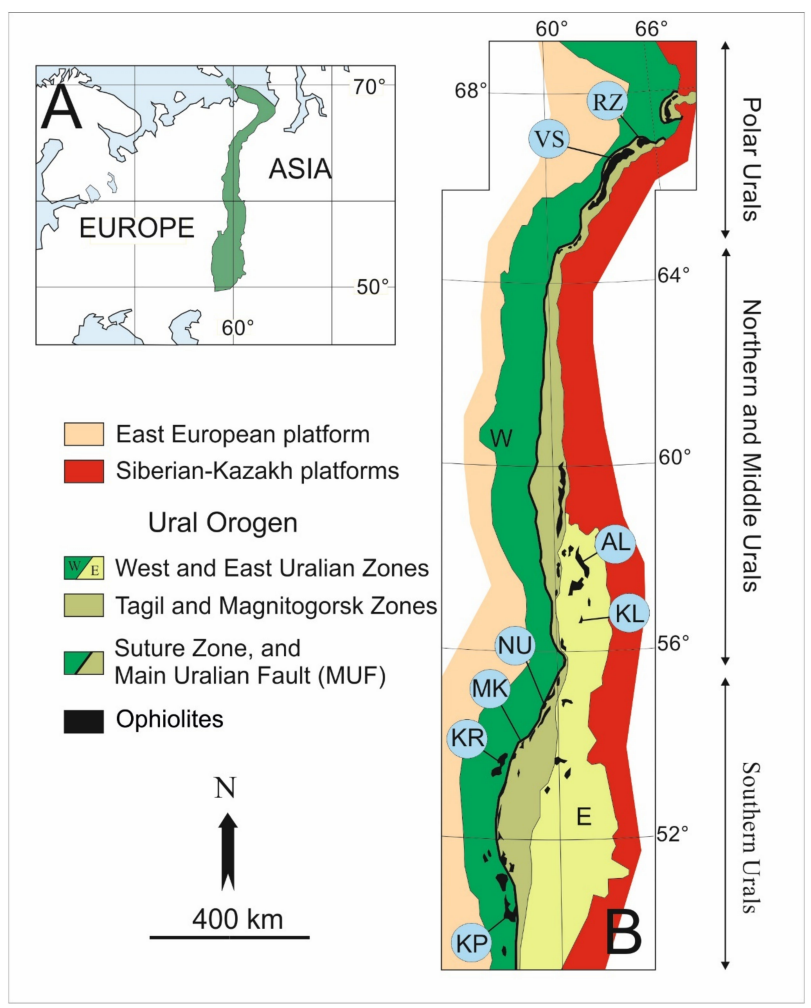

Figure 1. Geographic location of the Ural Orogenic Belt, marking the border between Europe and Asia (A). Schematic geological map of the Ural lithostratigraphic units, and distribution of the principal ophiolite complexes (B). From north to south: RZ = Ray-Iz, VS = Voykar Syninsky, AL = Alapaevsk, $\mathrm{KL}=$ Kluchevskoy, NU = Nurali, $\mathrm{MK}=$ Mindyak, KR = Kraka, KP = Kempirsai. Modified after [34]. 
Major ophiolite complexes occur from the Polar to the Southern Ural along the Main Uralian Fault, either to the east (Ray-Iz, Voykar Syninsky), or to the west (Kempirsai, Kraka) of the "Suture Zone" (Figure 1B). Others occur as tectonic slices inserted in the Suture Zone (Nurali, Mindyak), or located far eastwards within the East Uralian Zone (Alapaevsk, Kluchevskoy). These ophiolites display a wide spectrum of mantle tectonite varying from HOT to LOT petrologic association, indicating exhumation of the oceanic lithosphere from different paleogeographic regions and subduction-related or subduction-unrelated tectonic settings [11,14,34-41].

\subsection{Local Geology of the Kraka Massif}

The Kraka ophiolite massifs lies completely displaced westward of the Main Uralian Fault (MUF), forming an allochthonous nappe tectonically thrust onto the European continental plate, in the south of the West Uralian Zone (Figure 1B). The ophiolite covers an area of about $1200 \mathrm{~km}^{2}$ (Figure 2), including four plutonic blocks (Northern Kraka, Middle Kraka, Southern Kraka, and Uzyansky Kraka) and an allochthonous suite of volcanosedimentary rocks. These allochthonous terranes (Ordovician-Silurian) are separated from autochthonous sediments (Ordovician-Devonian-Carboniferous) by a thick horizon of serpentinite melange marking the tectonic over-thrust plane [36]. Geophysical data proved that the plutonic blocks extend some kilometers below surface with a total thickness from $1-2 \mathrm{~km}$ to a maximum of 3-4 km.

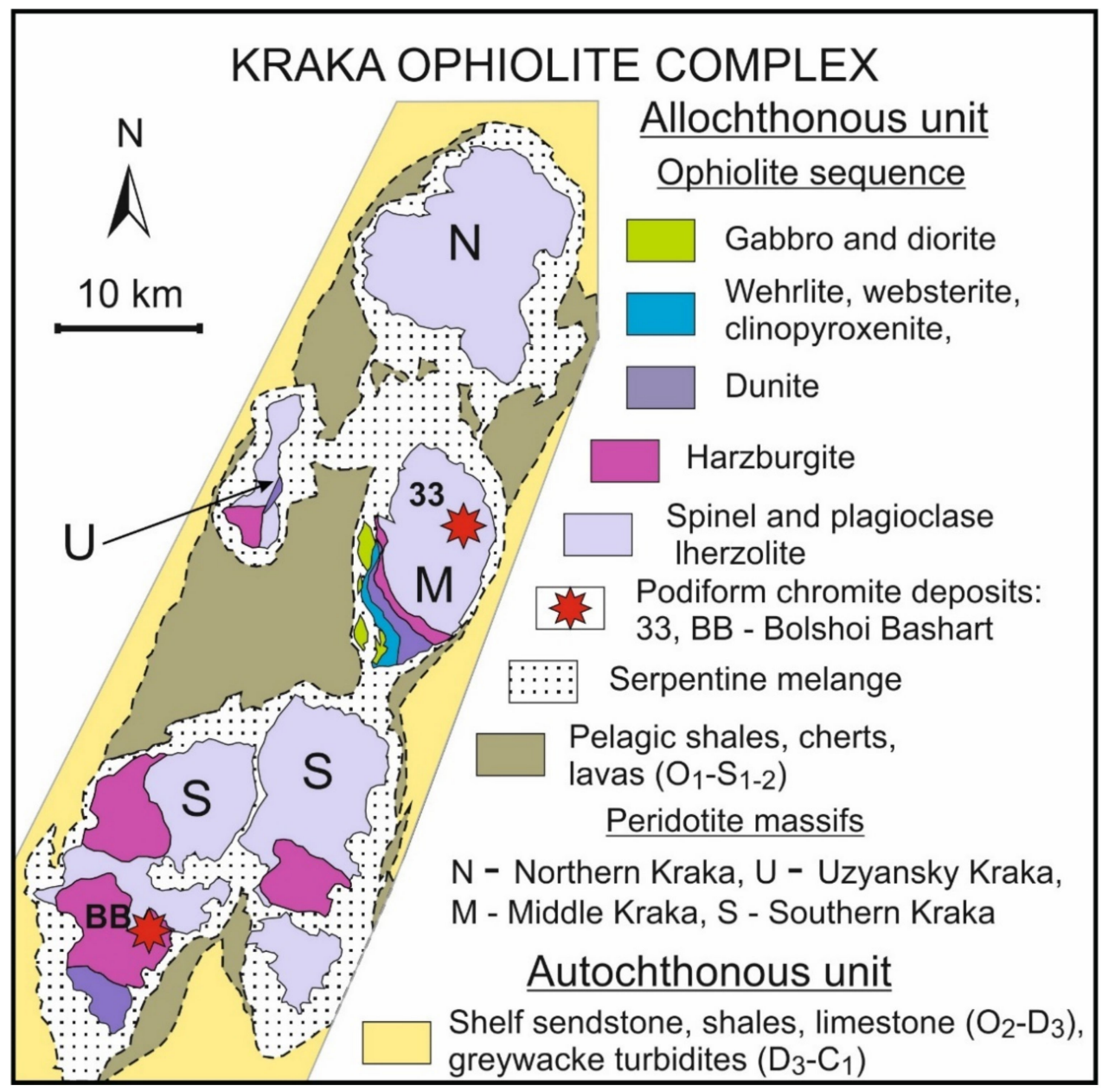

Figure 2. Simplified geological map of the Kraka ophiolite massif, showing the locations of the chromite deposits of Bolshoi Bashart (BB) and Prospect 33 (33). Modified after [39]. 
The ophiolite is dominated by LOT mantle tectonite with a very limited pile of crustal cumulates (dunite, wehrlite, websterite, clinopyroxenite, gabbroic rocks) exposed in the small Middle Kraka block $\left(\sim 120 \mathrm{~km}^{2}\right)$ [30,39]. The mantle tectonite mainly consists of lherzolite in the Northern, Middle, and Uzyansky blocks. Abundant lherzolite and harzburgite with subordinate dunite constitute the largest block of Southern Kraka $\left(\sim 470 \mathrm{~km}^{2}\right)$ [30,39].

Compared with Kempirsai and Ray-Iz, the tectonite section of Kraka contains a much higher proportion of lherzolite representing one of the least depleted mantle sections of the Urals, possibly not strictly related to subduction but exhumed from a region immediately to the east of the European continent $[30,34,37,38,40]$. The Kraka ophiolite has many characters in common with other LOT massifs exposed between $52^{\circ}$ and $56^{\circ}$ Lat. N (e.g., Nurali, Mindyak) tectonically inserted in the Suture Zone of the Main Uralian Fault (MUF) (Figure 1B), which is assumed as the "root zone" for some ophiolite allochthones [34].

\section{Podiform Chromite Deposits of the Kraka Ophiolite}

\subsection{Occurrence}

Mining exploration in the Kraka ophiolite was undertaken from the early thirties onwards, and led to the discovery of several chromite occurrences and economic deposits, some of which amounted to more than 150 thousand tons ([31] and references therein). The largest deposits occur in the SW of Southern Kraka just below the Moho transition where the proportion of harzburgite-dunite to lherzolite is higher (Figure 2). Surface and underground mining works in the deposit of BB revealed the presence of various elongated and boudinaged chromite lenses $0.5-2.5 \mathrm{~m}$ thick, extending over several tens of meters inside interlayered harzburgite-dunite that is deeply serpentinized ([31] and references therein). The chromitite horizon may extend $1.5-2 \mathrm{~km}$ along the strike, dipping $10-15^{\circ}$ and 35-50 northwards.

The Middle Kraka block contains two types of chromitite: one sub-economic (not indicated in Figure 2) is confined to the W of the block, and consists of veins a few centimeters long, associated with the dunite-pyroxenite-gabbro cumulus pile [31]. Since these chromitites formally are "stratiform" deposits not pertaining to the mantle tectonite suite, they were not considered as relevant to the purpose of this work. The most important chromite deposit in the area (Prospect 33) occurs far below the Moho transition, in the deep segment of the lherzolite mantle tectonite (Figure 2). The deposit was discovered in 1935 and was estimated to contain about 2000 tons of chromite reserves, most of which were mined recently. The ore bodies form veins and lenses are up to $2 \mathrm{~m}$ thick and more than $40 \mathrm{~m}$ long, inside a dunite pod that separates the chromitite from the lherzolite host [31].

Field relations suggest that both the BB and the Prospect 33 podiform chromitite deposits were precipitated due to a reaction between the residual mantle and draining mafic magmas after a major event of plastic flow.

\subsection{Chromite Texture and Composition}

In both deposits of Kraka, the dunite-chromitite assemblage displays similar structures and field relations. The most common ore type exposed in a small open pit of deposit 33 (Figure 3A) is massive chromitite consisting of up to $90 \%$ of modal chromite, in sharp contact with the host dunite (Figure 3B). The massive chromitite contains pods of highgrade disseminated ore (about 50\% of modal chromite) (Figure 3C), and patches of nodular ore and occluded silicate matrix (Figure 3D,E). Nodules up to 1-2 cm in size appear as sections of undeformed spherules disseminated in the dunite groundmass. Chromite schlieren, veinlets, and seams also occur in interlayerd lherzolite and dunite (Figure 3F). Under the microscope, the massive chromitite appears as a solid aggregate of closely interlocked chromite crystals, cut by cracks and fissures, and spotted with irregular silicate patches larger than $100 \mu \mathrm{m}$, and minute silicate inclusions (Figure 4A,B). The volume of silicate may increase up to 10-30\%, forming a continuous network interstitial to chromite aggregates (Figure 4C,D). Networked chromitite usually degrades into a dissemination 
of chromite grains in the dunite matrix. Chromite is generally fresh, showing the typical alteration into ferrian-chromite along grain boundaries and cracks (Figure $4 \mathrm{E}, \mathrm{F}$ ).
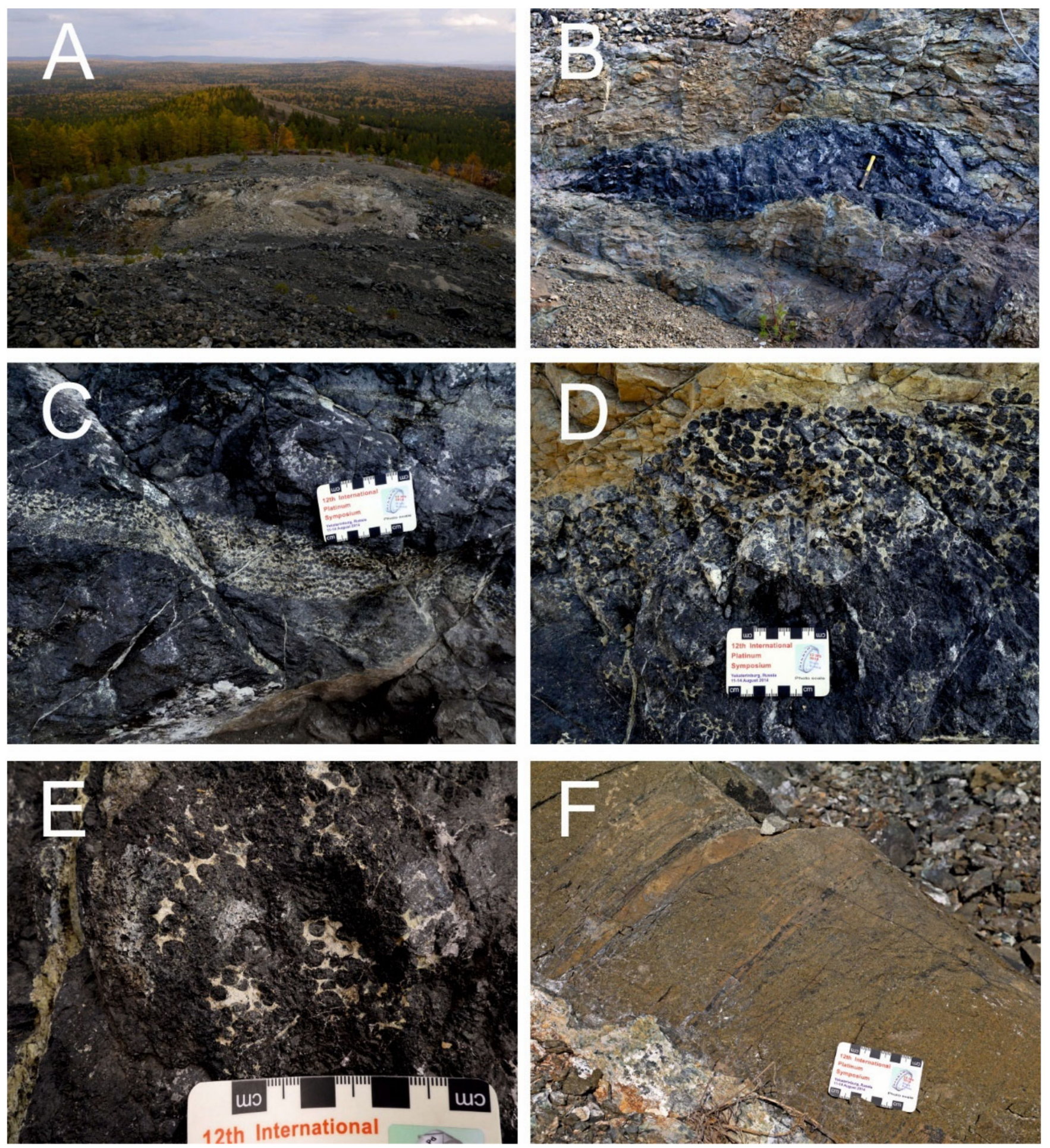

Figure 3. Field images of the Prospect 33 chromite deposit. View of the exploration open pit (A). A massive lens of chromitite in sharp contact with the host dunite (B). Irregular pods of high-grade disseminated ore inside massive chromitite (C). Nodular ore composed of 1-2 cm chromite spherules (D,E). Ore-hosting lherzolite-dunite interbedded sequence. Dunite $=$ yellow; lherzolite $=$ gray-yellowish; dark layers are strongly serpentinized zones $(\mathbf{F})$. Photographs by E. Pushkarev . 

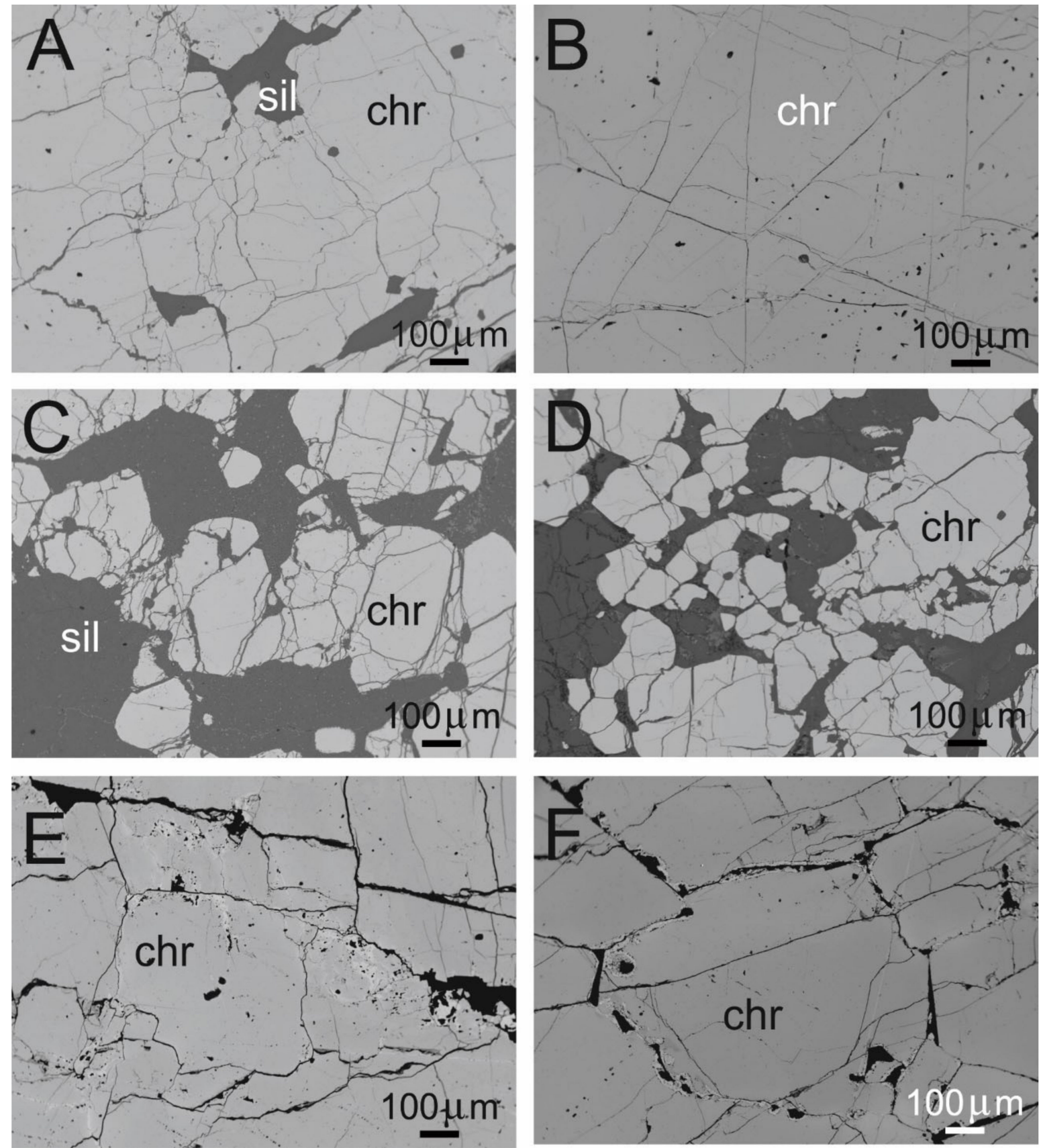

Figure 4. Back scattered electron (BSE) images of the chromite texture. Massive chromitite composed of closely interlocked chromite crystals cut by cracks and fissures, and spotted with silicate patches larger than $100 \mu \mathrm{m}$, and minute silicate inclusions (A,B). Networked chromitite containing up to 10-30\% interstitial silicate (C,D). Chromite showing incipient alteration into ferrian-chromite along grain boundaries and cracks (E,F). Bolshoi Bashart samples BB7619 (A), BB7616 (C), and BB7612 (E); Prospect 33 samples PE1757(B), PE1758 (D), and PE1755 (F).

Both the Kraka deposits consist of high-Cr chromite $(\mathrm{Cr} \#=0.70-0.83)$ similar to boninite-derived chromitites. They have constant concentrations of $\mathrm{FeO}(11.8-11.1 \mathrm{wt} \%)$ and $\mathrm{MgO}(14.4 \mathrm{wt} \%)$, but exhibit different $\mathrm{Cr}_{2} \mathrm{O}_{3}$ and $\mathrm{Al}_{2} \mathrm{O}_{3}$ contents (Table 1) and low chromium numbers, from $\mathrm{Cr} /(\mathrm{Cr}+\mathrm{Al})=0.79-0.83$ in the deposit 33 to $0.70-0.79$ in the $\mathrm{BB}$ mine (Figure $5 \mathrm{~A}$ ). The $\mathrm{TiO}_{2}$ content increases from $0.12 \mathrm{wt} \%$ to $0.24 \mathrm{wt} \%$ with increasing $\mathrm{Fe}^{2+} /\left(\mathrm{Fe}^{2+}+\mathrm{Mg}\right)$ as a result of differentiation of the chromite parent melt [14] (Figure 5B). Notably, the oxidation state of chromite expressed as the $\mathrm{Fe}^{3+} /\left(\mathrm{Fe}^{2+}+\mathrm{Fe}^{3+}\right)$ atomic ratio is higher in deposit 33 (Figure 5C). 
Table 1. Electron microprobe compositions ( $w \mathrm{t} \%$ ) of chromite from chromitites of the the Kraka ophiolite complex.

\begin{tabular}{|c|c|c|c|c|c|c|c|c|c|c|c|c|c|}
\hline Sample & BB7612 & BB7615 & BB7616 & BB7618 & BB7619 & BB X1 & BB X2 & BB X3 & PE1754 & PE1755 & PE1757 & PE1758 & PE1764 \\
\hline $\begin{array}{l}\text { Ore } \\
\text { type }\end{array}$ & mas & mas & mas & mas & mas & mas & dis & mas & nod & mas & mas & nod & $\begin{array}{l}\text { micro- } \\
\text { nod }\end{array}$ \\
\hline $\begin{array}{c}\mathrm{n}^{\circ} \\
\text { anal. }\end{array}$ & (6) & (6) & (14) & (6) & (26) & (5) & (10) & (8) & (20) & (20) & (20) & (20) & (20) \\
\hline $\mathrm{SiO}_{2}$ & 0.02 & 0.01 & 0.00 & 0.06 & 0.00 & 0.00 & 0.00 & 0.00 & 0.00 & 0.00 & 0.00 & 0.00 & 0.00 \\
\hline $\mathrm{TiO}_{2}$ & 0.17 & 0.14 & 0.21 & 0.15 & 0.16 & 0.17 & 0.15 & 0.23 & 0.18 & 0.19 & 0.21 & 0.19 & 0.12 \\
\hline $\mathrm{Al}_{2} \mathrm{O}_{3}$ & 12.03 & 11.37 & 14.98 & 11.98 & 13.99 & 12.77 & 10.77 & 10.72 & 8.35 & 9.90 & 10.38 & 8.85 & 8.23 \\
\hline $\mathrm{FeO}$ & 11.48 & 11.41 & 10.94 & 11.56 & 12.25 & 11.56 & 12.80 & 11.94 & 10.45 & 10.70 & 11.68 & 11.84 & 10.23 \\
\hline $\mathrm{Fe}_{2} \mathrm{O}_{3}$ & 3.20 & 4.67 & 4.88 & 4.62 & 5.49 & 4.62 & 3.30 & 3.26 & 5.22 & 5.03 & 4.35 & 4.66 & 5.42 \\
\hline $\mathrm{MgO}$ & 14.42 & 14.33 & 15.07 & 14.27 & 14.48 & 14.45 & 13.51 & 13.97 & 14.61 & 14.52 & 14.14 & 13.78 & 14.66 \\
\hline $\mathrm{MnO}$ & 0.15 & 0.22 & 0.23 & 0.17 & 0.26 & 0.21 & 0.30 & 0.24 & 0.34 & 0.31 & 0.40 & 0.40 & 0.38 \\
\hline $\mathrm{Cr}_{2} \mathrm{O}_{3}$ & 57.53 & 57.17 & 52.69 & 55.81 & 54.36 & 55.46 & 58.89 & 58.48 & 60.03 & 58.05 & 58.71 & 59.69 & 60.05 \\
\hline $\mathrm{NiO}$ & 0.16 & 0.15 & 0.00 & 0.09 & 0.01 & 0.08 & 0.00 & 0.00 & 0.10 & 0.12 & 0.11 & 0.07 & 0.09 \\
\hline $\mathrm{ZnO}$ & 0.03 & 0.13 & 0.00 & 0.12 & 0.00 & 0.06 & 0.00 & 0.00 & 0.02 & 0.03 & 0.02 & 0.02 & 0.02 \\
\hline $\mathrm{V}_{2} \mathrm{O}_{3}$ & 0.11 & 0.07 & 0.00 & 0.08 & 0.01 & 0.05 & 0.00 & 0.00 & 0.03 & 0.03 & 0.02 & 0.04 & 0.03 \\
\hline Total & 99.31 & 99.67 & 99.02 & 98.91 & 101.01 & 99.44 & 99.72 & 98.85 & 99.33 & 98.88 & 100.03 & 99.54 & 99.23 \\
\hline $\mathrm{Cr} \#$ & 0.76 & 0.77 & 0.70 & 0.76 & 0.72 & 0.74 & 0.79 & 0.79 & 0.83 & 0.80 & 0.79 & 0.82 & 0.83 \\
\hline $\mathrm{Mg \#}$ & 0.69 & 0.69 & 0.71 & 0.69 & 0.68 & 0.69 & 0.65 & 0.68 & 0.71 & 0.71 & 0.68 & 0.67 & 0.72 \\
\hline $\mathrm{Fe}^{3+} \#$ & 0.04 & 0.06 & 0.06 & 0.06 & 0.06 & 0.06 & 0.04 & 0.04 & 0.06 & 0.06 & 0.05 & 0.06 & 0.07 \\
\hline
\end{tabular}

$\mathrm{BB}=$ Southern Kraka (Balshoi Bashart mine). PE = Middle Kraka (Deposit 33). Ore type: mas = massive, dis = high-grade disseminated, nod $=$ nodular, $\mathrm{n}^{\circ}$ anal. $=$ number of averaged analyses.
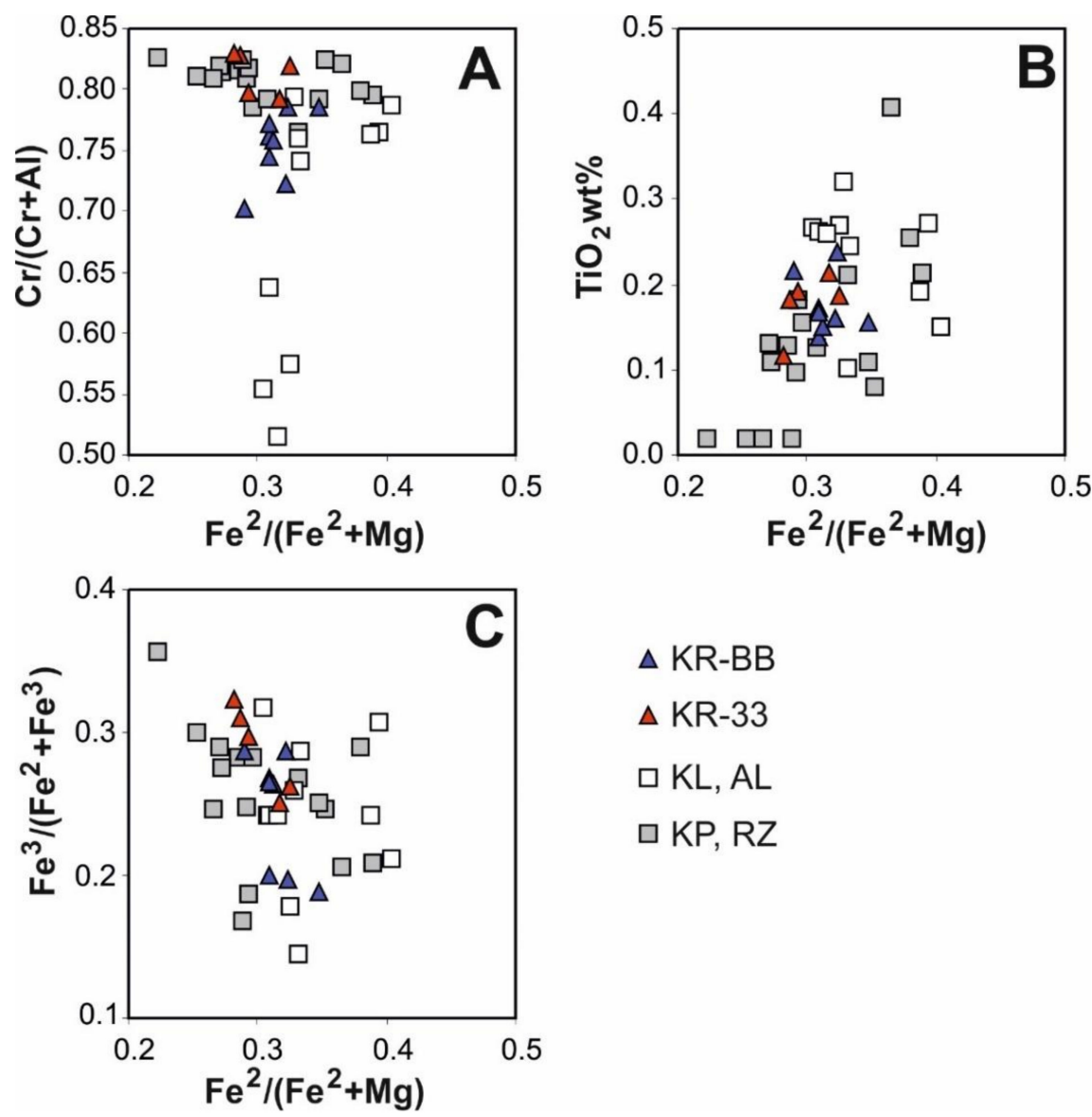
$\Delta \mathrm{KR}-\mathrm{BB}$
$\Delta \mathrm{KR}-33$
$\square \mathrm{KL}, \mathrm{AL}$
$\square \mathrm{KP}, \mathrm{RZ}$

Figure 5. Compositional variations of chromite from Prospect 33 (KR-33) to Bolshoi Bashart (KR-BB) showing a decrease in chromium number $\mathrm{Cr} /(\mathrm{Cr}+\mathrm{Al})=0.83-0.79$ to $0.79-0.70(\mathbf{A})$; an increase in $\mathrm{TiO}_{2}, 0.12-0.24 \mathrm{wt} \%(\mathbf{B})$; and an increase of the chromite oxidation state $(\mathbf{C})$, with an increasing degree of differentiation expressed as $\mathrm{Fe}^{2+} /\left(\mathrm{Fe}^{2+}+\mathrm{Mg}\right)$. The compositions of chromite from other chromite deposits of the Urals are shown for comparison: Alapaevsk (AL), Kluchevskoy (KL), Kempirsai (KP), and Ray-Iz (RZ) (data from [12,14,27]). 


\subsection{Solid Inclusions in Chromite}

The mafic silicates occurring included in unaltered chromite are mainly olivine, clinopyroxene (Figure 6A,B), rare orthopyroxene, and minor amphibole. The inclusions have polygonal or rounded shapes. However, in the BB ore body, penetrative serpentinization has transformed the mafic silicates into chlorite and serpentine. Some composite inclusions consist of mafic silicates and undetermined $\mathrm{Ni}$ and $\mathrm{Cu}$ sulfides (Figure 6C,D). The sulfides enclosed in fresh chromite grains are considered to be primary in origin, and distinguished from sulfides formed at low temperature, mainly heazlewoodite, which occur along cracks in association with ferrian chromite, serpentine, and chlorite. Millerite and rare pentlandite may also occur as drop-like grains $(<30 \mu \mathrm{m})$ disseminated in the chromite.
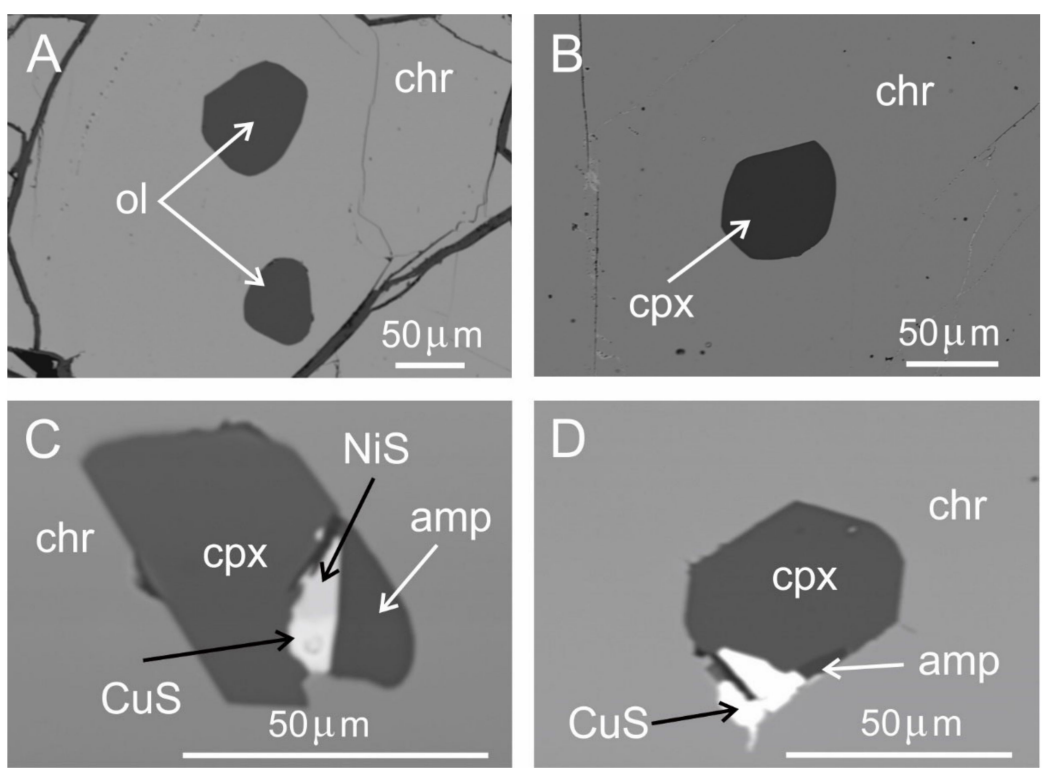

Figure 6. BSE images of mafic-silicate inclusions in chromite of the Kraka deposits. Polygonal and rounded olivine, sample PE1758 (A); subrounded clinopyroxene, sample PE1757 (B); composite inclusions of clinopyroxene and amphibole associated with $\mathrm{Ni}$ and $\mathrm{Cu}$ sulfides, sample PE1757b2 (C) and sample PE1757b5 (D). Abbreviations: $\mathrm{Chr}=$ chromite; $\mathrm{Ol}=$ olivine; $\mathrm{Cpx}=$ clinopyroxene; Am $=$ amphibole; $\mathrm{NiS}=\mathrm{Ni}$ sulfide; $\mathrm{CuS}=\mathrm{Cu}$ sulfide. The dark lamellar silicate associated with the sulfides in picture $(\mathbf{C}, \mathbf{D})$ is chlorite.

The olivine included in the chromite of Prospect 33 is more forsteritic and $\mathrm{NiO}$ rich compared with olivine inclusions in the BB deposit that are significantly depleted in both $\mathrm{Mg}$ and $\mathrm{Ni}$ (Table 2). Trends of decreasing forsterite and $\mathrm{NiO}$ in olivine from deposit 33 to the $\mathrm{BB}$ (Figure 7) were observed. The NiO content of olivine decreases remarkably from about $1.0 \mathrm{wt} \%$ down to $0.3 \mathrm{wt} \%$, approaching the composition of olivine in the mantle peridotite. The same trend is present in olivine inclusions in chromitite of the other chromite deposits of the Urals (Figure 7).

Table 2. Electron microprobe compositions ( $\mathrm{w} t \%$ ) of accessory olivine from the Kraka chromitites.

\begin{tabular}{|c|c|c|c|c|c|c|c|c|c|c|c|c|c|}
\hline Sample & BB7619 & BB $\times 1$ & BB $\times 2$ & BB $\times 3$ & BB $\times 4$ & BB $\times 5$ & BB $\times 6$ & BB $\times 7$ & BB $\times 8$ & PE1758 & PE1758 & PE1754 & PE1764 \\
\hline $\begin{array}{c}\mathrm{n}^{\circ} \\
\text { anal. }\end{array}$ & (12) & - & - & - & - & - & - & - & - & (2) & (55) & (4) & (28) \\
\hline $\mathrm{SiO}_{2}$ & 41.13 & 40.97 & 41.26 & 40.84 & 41.69 & 42.89 & 43.23 & 41.10 & 40.91 & 49.22 & 41.77 & 47.10 & 41.46 \\
\hline $\mathrm{TiO}_{2}$ & 0.01 & 0.00 & 0.00 & 0.02 & 0.01 & 0.00 & 0.01 & 0.02 & 0.01 & 0.00 & 0.05 & 0.03 & 0.04 \\
\hline $\mathrm{Al}_{2} \mathrm{O}_{3}$ & 0.04 & 0.06 & 0.05 & 0.02 & 0.00 & 0.01 & 0.00 & 0.02 & 0.00 & 0.41 & 0.00 & 0.00 & 0.01 \\
\hline $\mathrm{FeO}$ & 6.85 & 6.87 & 7.01 & 7.08 & 6.73 & 2.50 & 2.70 & 7.01 & 6.84 & 1.91 & 2.93 & 2.98 & 2.56 \\
\hline $\mathrm{MgO}$ & 50.89 & 51.01 & 50.68 & 50.24 & 50.69 & 52.55 & 51.44 & 50.26 & 50.72 & 45.66 & 52.75 & 47.26 & 51.98 \\
\hline $\mathrm{MnO}$ & 0.09 & 0.10 & 0.07 & 0.09 & 0.10 & 0.02 & 0.04 & 0.09 & 0.07 & 0.08 & 0.04 & 0.05 & 0.03 \\
\hline $\mathrm{CaO}$ & 0.04 & 0.04 & 0.04 & 0.06 & 0.02 & 0.00 & 0.00 & 0.01 & 0.00 & 0.04 & 0.01 & 0.01 & 0.02 \\
\hline $\mathrm{Na}_{2} \mathrm{O}$ & 0.11 & 0.01 & 0.03 & 0.19 & 0.17 & 0.00 & 0.00 & 0.06 & 0.05 & 0.04 & 0.01 & 0.00 & 0.01 \\
\hline
\end{tabular}


Table 2. Cont.

\begin{tabular}{|c|c|c|c|c|c|c|c|c|c|c|c|c|c|}
\hline Sample & BB7619 & BB X 1 & BB X 2 & BB X 3 & BB X 4 & BB X 5 & BB X 6 & BB X 7 & BB X 8 & PE1758 & PE1758 & PE1754 & PE1764 \\
\hline $\mathrm{K}_{2} \mathrm{O}$ & 0.00 & 0.00 & 0.00 & 0.00 & 0.00 & 0.00 & 0.00 & 0.18 & 0.01 & 0.00 & 0.00 & 0.00 & 0.00 \\
\hline $\mathrm{Cr}_{2} \mathrm{O}_{3}$ & 0.02 & 0.00 & 0.08 & 0.01 & 0.00 & 0.47 & 0.15 & 0.00 & 0.00 & 0.01 & 0.52 & 0.66 & 1.03 \\
\hline $\mathrm{NiO}$ & 0.33 & 0.31 & 0.38 & 0.26 & 0.34 & 0.78 & 0.75 & 0.26 & 0.33 & 0.33 & 0.82 & 1.07 & 0.95 \\
\hline $\mathrm{ZnO}$ & 0.05 & 0.00 & 0.07 & 0.07 & 0.05 & 0.11 & 0.00 & 0.07 & 0.09 & 0.00 & 0.00 & 0.00 & 0.00 \\
\hline $\mathrm{V}_{2} \mathrm{O}_{3}$ & 0.00 & 0.00 & 0.02 & 0.00 & 0.00 & 0.02 & 0.00 & 0.00 & 0.00 & 0.00 & 0.00 & 0.00 & 0.00 \\
\hline Total & 99.56 & 99.37 & 99.70 & 98.88 & 99.80 & 99.33 & 98.32 & 99.08 & 99.04 & 97.69 & 98.90 & 99.16 & 98.09 \\
\hline $\mathrm{Fo} \%$ & 93.0 & 93.0 & 92.8 & 92.7 & 93.1 & 97.4 & 97.1 & 92.7 & 93.0 & 97.7 & 97.0 & 96.6 & 97.3 \\
\hline
\end{tabular}

$\mathrm{BB}=$ Southern Kraka (Balshoi Bashart mine). PE = Middle Kraka (Deposit 33). Fo\% = Percent of forsterite expressed as $100 \mathrm{Mg} /\left(\mathrm{Mg}+\mathrm{Fe}{ }^{2}\right.$ ). $\mathrm{n}^{\circ}$ anal. $=$ number of averaged analyses

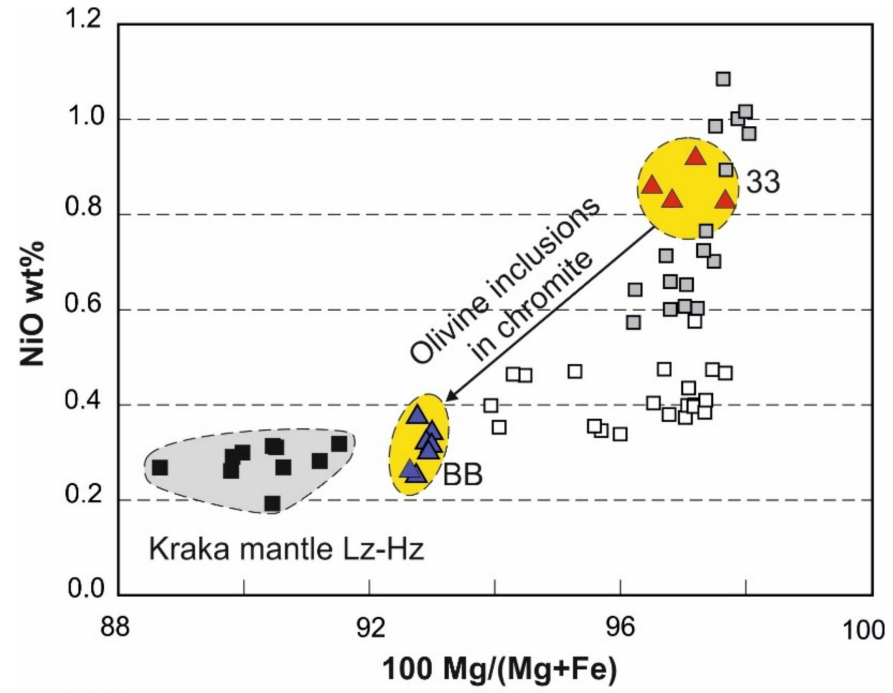

$\Delta \mathrm{KR}-\mathrm{BB} \quad \Delta \mathrm{KR}-33 \quad \square \mathrm{KL}, \mathrm{AL} \quad \square \mathrm{KP}, \mathrm{RZ}$

- Kraka olivine in $\mathrm{Lz}-\mathrm{Hz}$

Figure 7. Compositional variations of olivine inclusions in chromite define trends of decreasing forsterite and $\mathrm{NiO} w \mathrm{t} \%$ from Prospect 33 (KR-33) to Bolshoi Bashart (KR-BB), reflecting differentiation of the chromite parent melt during ascent to the mantle/crust transition zone. The same trend is visible in olivine inclusions in the chromitites of the other chromite deposits of the Urals: Alapaevsk (AL), Kluchevskoy (KL), Kempirsai (KP), and Ray-Iz (RZ) (data from [12,14,27]). The field of olivine from the Kraka mantle lherzolite $(\mathrm{Lz})$ and harzburgite $(\mathrm{Hz})$ is shown for comparison.

The clinopyroxene in chromitite 33 (Table 3 ) corresponds to the composition of diopside $\mathrm{En}_{45-50} \mathrm{Fs}_{2-3} \mathrm{Wo}_{53-47}$, having higher $\mathrm{Na}_{2} \mathrm{O}$ and $\mathrm{Cr}_{2} \mathrm{O}_{3}$ contents compared with clinopyroxene from mantle chromitites of the Urals (Figure $8 \mathrm{~A}, \mathrm{~B}$ ). Solitary inclusions of amphibole were not encountered. Notably, the amphibole occurring in composite inclusions of chromitite 33 (Table 3) has higher $\mathrm{Na}$ content at a given $\mathrm{Al} / \mathrm{Si}$, compared with the amphibole from the Kempirsai chromitites (Figure 8C,D).

Table 3. Electron microprobe compositions ( $\mathrm{wt} \%$ ) of clinopyroxene and amphibole inclusions in chromite of Prospect 33 from the Kraka mantle tectonite.

\begin{tabular}{ccccccccccc}
\hline \multicolumn{7}{c}{ Clinopyroxene } & \multicolumn{9}{c}{ Amphibole } \\
\hline Sample & PE1754 & PE1755 & PE1757 & PE1757b & PE1758 & PE1757 & PE1757 & PE1757 & PE1757b & PE1757b \\
\hline texture & included & included & included & included & included & included & included & included & included & included \\
\hline $\mathrm{n}^{\circ}$ anal. & $(3)$ & $(40)$ & $(17)$ & $(3)$ & $(7)$ & - & - & - & - & - \\
\hline $\mathrm{SiO}_{2}$ & 54.76 & 54.72 & 54.87 & 55.50 & 55.22 & 47.87 & 48.59 & 48.64 & 52.54 & 53.89 \\
\hline $\mathrm{TiO}_{2}$ & 0.02 & 0.11 & 0.09 & 0.20 & 0.17 & 0.55 & 0.28 & 0.34 & 0.23 & 0.42 \\
\hline $\mathrm{Al}_{2} \mathrm{O}_{3}$ & 1.14 & 1.27 & 1.32 & 0.99 & 1.02 & 7.87 & 7.67 & 8.27 & 7.81 & 8.99 \\
\hline
\end{tabular}


Table 3. Cont.

\begin{tabular}{cccccccccccc}
\hline \multicolumn{7}{c}{ Clinopyroxene } & \multicolumn{9}{c}{ Amphibole } \\
\hline $\mathrm{FeO}$ & 1.39 & 1.29 & 1.36 & 1.13 & 1.43 & 1.35 & 1.40 & 1.50 & 1.12 & 1.58 \\
\hline $\mathrm{MgO}$ & 15.00 & 14.26 & 17.05 & 15.59 & 17.42 & 20.04 & 20.37 & 20.51 & 16.35 & 10.84 \\
\hline $\mathrm{MnO}$ & 0.02 & 0.04 & 0.04 & 0.04 & 0.03 & 0.05 & 0.01 & 0.02 & 0.04 & 0.02 \\
\hline $\mathrm{CaO}$ & 22.56 & 23.43 & 22.76 & 23.82 & 22.82 & 12.37 & 12.32 & 12.26 & 13.67 & 14.33 \\
\hline $\mathrm{Na}_{2} \mathrm{O}$ & 0.86 & 0.53 & 0.85 & 0.67 & 0.76 & 2.66 & 2.69 & 2.64 & 2.49 & 2.29 \\
\hline $\mathrm{K}_{2} \mathrm{O}$ & 0.00 & 0.01 & 0.00 & 0.00 & 0.00 & 0.16 & 0.14 & 0.16 & 0.13 & 0.01 \\
\hline $\mathrm{Cr}_{2} \mathrm{O}_{3}$ & 2.63 & 2.55 & 2.38 & 2.04 & 2.26 & 4.08 & 3.31 & 3.55 & 2.84 & 3.62 \\
\hline $\mathrm{NiO}$ & 0.05 & 0.07 & 0.06 & 0.02 & 0.06 & 0.24 & 0.22 & 0.18 & 0.21 & 0.23 \\
\hline $\mathrm{Total}$ & 98.42 & 98.27 & 100.78 & 100.00 & 101.18 & 97.22 & 97.01 & 98.07 & 97.43 & 96.21 \\
\hline
\end{tabular}

$\mathrm{PE}=$ Middle Kraka (Deposit 33). All grains occur as inclusions in chromite. $\mathrm{n}^{\circ}$ anal. $=$ number of averaged analyses.
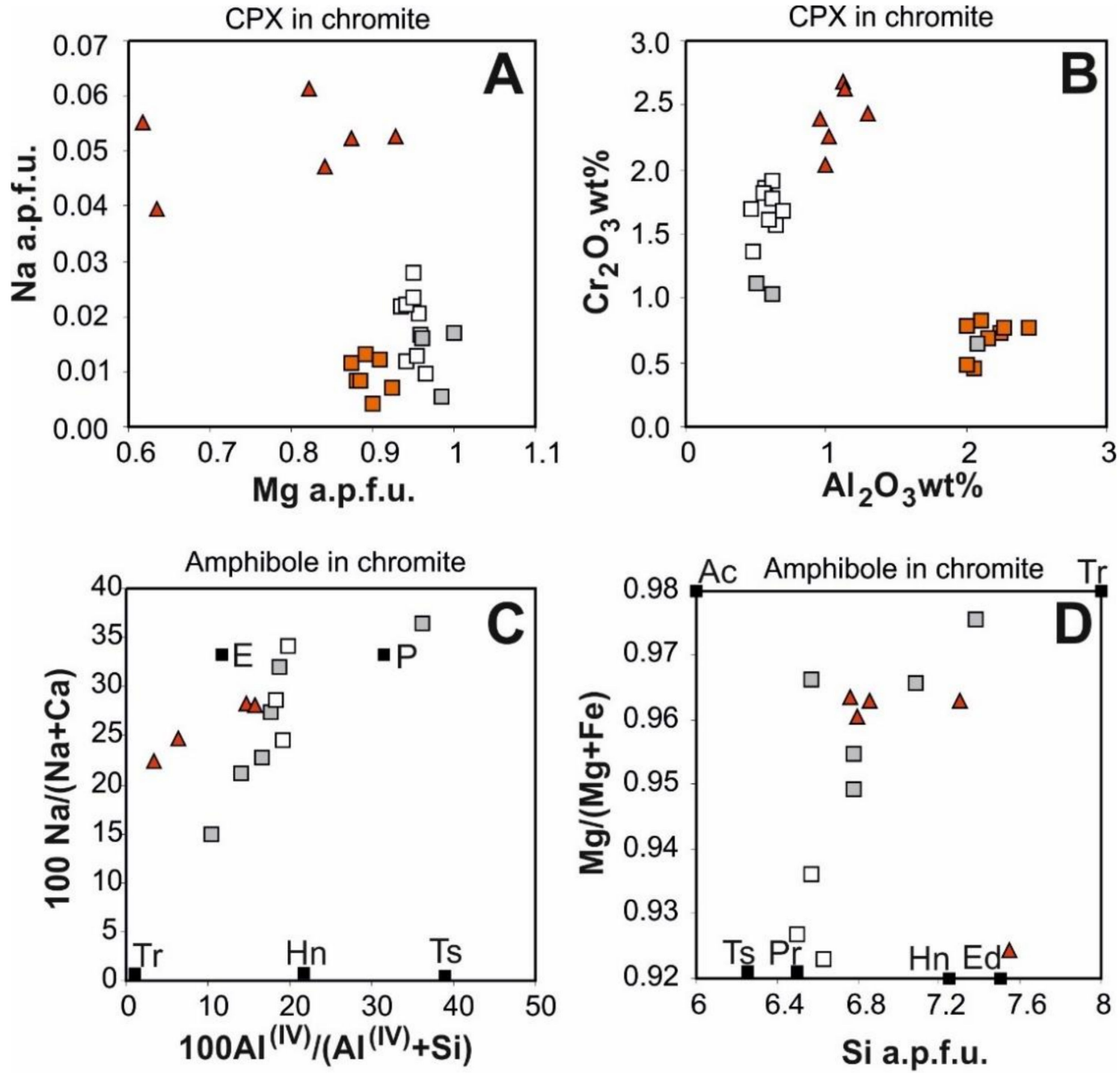
$\Delta \mathrm{KR}-33$
$\square \mathrm{AL}$
口 KP
$\Delta$ VS

Figure 8. The clinopyroxene included in chromitite Prospect 33 (KR-33) is Na-rich and Cr-rich diopside (A,B). Amphibole occurring in composite inclusions is edenite-pargasitic hornblende, tending toward tremolite (C,D). Clinopyroxene and amphibole from Kraka are enriched in $\mathrm{Na}$ and $\mathrm{Cr}$ compared with chromitites Alapaevsk (AL), Kempirsai (KP), and Voykar Syninsky (VS). Abbreviations: $\mathrm{Cpx}=$ clinopyroxene; $\mathrm{E}=$ edenite; $\mathrm{P}=$ pargasite; $\mathrm{Tr}=$ tremolite; Hn = hornblende; $\mathrm{Ts}=$ tschermakite; $\mathrm{Ac}=$ actinolite, a.p.f.u. = atoms per formula unit. 


\subsection{Composition of the Chromitite Parent Melt}

Compositions of melts parent to the chromite deposits of Kraka were calculated with the equations proposed by Ballhaus with coauthors [42] and yielded very similar results, suggesting that both deposits resulted from the same influx of magma (Table 4). Weak but consistent increases in $\mathrm{Al}_{2} \mathrm{O}_{3}, \mathrm{FeO} / \mathrm{MgO}$, and $\mathrm{TiO}_{2}$, along with decreases in the Fo and $\mathrm{NiO}$ content of olivine (Figure 8) from the lower to the upper chromite deposit, were observed.

Table 4. Compositions ( $w \mathrm{t} \%$ ) of chromites and calculated parental melts for chromitites of the Urals compared with volcanic suites.

\begin{tabular}{|c|c|c|c|c|c|c|c|}
\hline & \multicolumn{5}{|c|}{ Chromite } & \multicolumn{2}{|l|}{ Melt } \\
\hline & $\mathbf{n}^{\circ}$ anal. & Cr\# & $\mathrm{TiO}_{2}$ & $\mathrm{FeO} / \mathrm{MgO}$ & $\mathrm{Al}_{2} \mathrm{O}_{3}$ & $\mathrm{TiO}_{2}$ & $\mathrm{FeO} / \mathrm{MgO}$ \\
\hline Kraka deposit 33 & 5 & 0.81 & 0.18 & 0.77 & 12.14 & 0.53 & 0.56 \\
\hline Kraka Bolshoi Bashart deposit BB & 7 & 0.76 & 0.19 & 0.83 & 13.00 & 0.55 & 0.64 \\
\hline \multicolumn{8}{|c|}{ High-Cr chromite deposits in Ophiolitic mantle tectonite of the Urals (§) } \\
\hline Voykar Syninsky & 10 & 0.80 & 0.14 & 1.15 & 10.78 & 0.23 & 0.85 \\
\hline Verkhneivinsky & 1 & 0.83 & 0.14 & 1.49 & 10.21 & 0.23 & 1.11 \\
\hline Ray-Iz & 46 & 0.80 & 0.10 & 0.89 & 10.81 & 0.19 & 0.66 \\
\hline Kempirsai & 170 & 0.81 & 0.16 & 0.76 & 10.84 & 0.26 & 0.56 \\
\hline Kluchevskoyoy & 58 & 0.76 & 0.19 & 1.10 & 11.71 & 0.29 & 0.83 \\
\hline Alapaevsk & 121 & 0.79 & 0.21 & 1.09 & 11.24 & 0.32 & 0.80 \\
\hline \multicolumn{8}{|l|}{ Spinels in Modern volcanic suites (§) } \\
\hline MORB (Mid oceanic ridge basalt) & 18 & 0.56 & 0.57 & 0.76 & 15.99 & 1.10 & 0.91 \\
\hline BAB (Back-arc basalt) & 1 & 0.45 & 0.41 & 0.60 & 17.72 & 1.29 & 0.80 \\
\hline OIB (Oceanic-island basalt) & 1 & 0.76 & 1.39 & 1.34 & 11.93 & 2.19 & 0.85 \\
\hline IAB (Island-arc high-K, calc-alkaline basalt) & 5 & 0.83 & 0.41 & 0.97 & 10.87 & 0.53 & 0.69 \\
\hline IABon IAT (Island-arc boninite, tholeiite) & 4 & 0.90 & 0.15 & 0.87 & 8.18 & 0.26 & 0.57 \\
\hline LIP (Large igneous provinces flood basalts) & 3 & 0.81 & 3.02 & 1.78 & 7.98 & 3.39 & 0.81 \\
\hline W. Greenland flood basalt & 1 & 0.69 & 0.97 & 1.32 & 14.69 & 1.84 & 1.36 \\
\hline Ankaramite & 7 & 0.82 & 0.55 & 1.23 & 9.65 & 0.69 & 1.03 \\
\hline
\end{tabular}

$\mathrm{n}^{\circ}$ anal. $=$ number of averaged analyses. $\mathrm{Cr} \#=\mathrm{Cr} /(\mathrm{Cr}+\mathrm{Al}) .(\S)=$ see text for calculation method and source of data.

The composition of the melt parent to the Kraka chromitites does not fit the boninitetype melt calculated for large chromite deposits in SSZ of the Urals (Ray-Iz, Kempirsai, Voykar Syninsky). The relatively high $\mathrm{Al}_{2} \mathrm{O}_{3}-\mathrm{TiO}_{2}$ contents inferred by chromite composition and the $\mathrm{Na}_{2} \mathrm{O}$-rich clinopyroxene in the Kraka deposits would indicate a more evolved character of the magma tending to MORB composition. The scarcity of amphibole in the Kraka chromitites supports that the melt was relatively "dry" compared with boninite of Kempirsai and Ray-Iz, where pargasitic amphibole is the most common silicate inclusion in chromite $[9,43]$.

\subsection{The Temperature and Oxygen Fugacity of the Chromitite Forming System}

The temperature and oxygen fugacity for the spinel-olivine equilibration in the deposit of Kraka were calculated using the equation of [42]. Although the obtained results (Table 5) may be unrealistic as absolute values, they are meaningful in the relative sense, showing that the chromitite-forming system in the BB deposit closed soon after chromite-olivine co-precipitation, in a thermal range of $1300-1100{ }^{\circ} \mathrm{C}$, whereas the system in deposit 33 closed at lower temperatures of $1100-800{ }^{\circ} \mathrm{C}$ (Figure 9).

The chromite-olivine equilibration involves diffusion of Fe from the silicate to the oxide [44,45], and at a constant chromite-olivine mass ratio, is favored by a slow cooling rate, or inhibited if cooling is rapid (quenching). Based on this assumption, we interpret the high temperature obtained from the BB samples as evidence that chromitite in the upper mantle section of Kraka crystallized and cooled more rapidly, compared with chromitite in the deep mantle lherzolite. 
Table 5. Temperature and oxygen fugacity for chromite-olivine pairs from the Kraka chromitites.

\begin{tabular}{|c|c|c|c|c|c|c|}
\hline \multicolumn{3}{|c|}{ Chromite } & \multicolumn{3}{|c|}{ Olivine } & \multirow[b]{2}{*}{$\Delta \log f\left(\mathrm{O}_{2}\right)$} \\
\hline Sample & Mg\# & Cr\# & $\mathrm{Fe}^{3} / \mathrm{Fe}^{2}+\mathrm{Fe}^{3}$ & Fo $\%$ & $\mathbf{T}^{\circ} \mathrm{C}$ & \\
\hline BB7619-12 & 0.70 & 0.75 & 0.27 & 93.0 & 1271 & 1.248 \\
\hline $\mathrm{BB} \times 2$ & 0.68 & 0.79 & 0.20 & 92.9 & 1256 & 1.137 \\
\hline $\mathrm{BB} \times 1$ & 0.65 & 0.79 & 0.19 & 92.9 & 1165 & 0.473 \\
\hline BB7619-11 & 0.66 & 0.75 & 0.19 & 93.0 & 1090 & 0.386 \\
\hline PE1754 & 0.71 & 0.83 & 0.31 & 96.6 & 1060 & 2.636 \\
\hline PE1764 & 0.72 & 0.83 & 0.32 & 97.3 & 982 & 3.076 \\
\hline PE1758 & 0.67 & 0.82 & 0.26 & 97.0 & 891 & 2.281 \\
\hline PE1758 & 0.67 & 0.82 & 0.26 & 97.7 & 809 & 2.670 \\
\hline
\end{tabular}

BB $=$ Southern Kraka (Balshoi Bashart mine). PE = Middle Kraka (Deposit 33). $\Delta \log f\left(\mathrm{O}_{2}\right)=$ oxygen fugacity as deviation from the fayalite-magnetite-quartz (FMQ) buffer. See text for calculation method and interpretative comments.

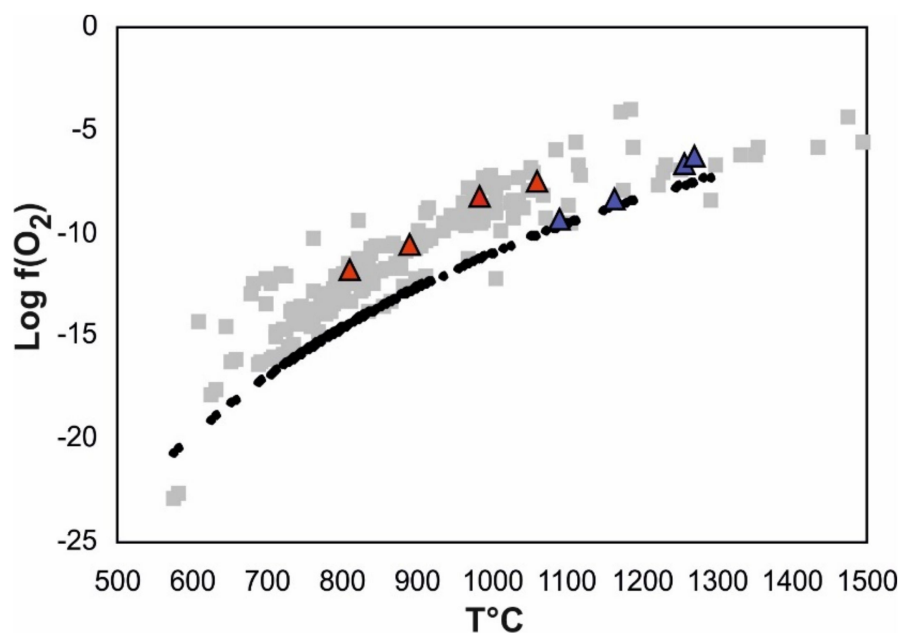

Figure 9. Variation in oxygen fugacity $\log \left(\mathrm{O}_{2}\right)$ as a function of temperature $\left(\mathrm{T}^{\circ} \mathrm{C}\right)$ calculated for chromite-olivine inclusions from the Kraka chromite deposits of Prospect 33 (red triangle) and Bolshoi Bashart (blue triangle). Gray squares are chromite-olivine inclusion pairs from Ray-Iz and Kempirsai giant chromite deposits (data from [14]). The dashed line is the FMQ buffer.

In deep mantle conditions, the chromite precipitation from the mafic melt lasted longer and probably extended to slightly lower temperatures, allowing sulfur fugacity to increase up to stabilization of high-energy Ir sulfides and erlichmanite [28]. The data points also indicate that the chromitite of BB equilibrated under a low oxygen fugacity, close to the FMQ threshold, in contrast with the 33 samples that yielded values two-three log-units above FMQ (Figure 9). This feature is consistent with the higher oxidation state in deposit 33 (see Figure 6C) indicating higher volatile fugacity in the magma that reacted with the deep mantle lherzolite.

These facts contribute to lowering the assumed liquidus temperature of the system. The precipitation of chromite might have produced a further increase in the sulfur fugacity by the extraction of $\mathrm{Fe}^{2+}$ from the magma. In the circumstances, more PGE clusters had the chance to convert into discrete PGM crystals before precipitation of chromite.

Temperatures below $700{ }^{\circ} \mathrm{C}$ would appear too low to represent chromite-olivine equilibration, and may reflect a breakdown of equilibrium due to a change in chromite composition in response to ferrian-chromite alteration during serpentinization [45]. 


\section{PGM in Chromitites of the Kraka Mantle Tectonite}

The chromitites of the BB deposit of Kraka are characterized by PGE concentrations between 43 and $58 \mathrm{ppb}$, which are among the lowest reported from chromitites of the Urals (Table 6). Chondrite-normalized PGE patterns [46] (Figure 10) have the negative slope characteristic of ophiolitic chromitites [47], with a variation trend similar to chromitites of Kluchevskoy [12]. The low PGE concentrations in the Kraka chromitites correspond to an overall shortage of PGM inclusions in the chromitite.

Table 6. Bulk rock PGE concentrations (ppb) in chromitite from the Bolshoi Bashart deposit (Southern Kraka).

\begin{tabular}{|c|c|c|c|c|c|}
\hline & BB7615 & BB7618 & BB7612 & BB7616 & BB7619 \\
\hline Os & 9.64 & 10.70 & 12.20 & 13.00 & 8.76 \\
\hline $\mathrm{Ir}$ & 6.30 & 10.30 & 8.83 & 9.89 & 5.78 \\
\hline $\mathrm{Ru}$ & 27.30 & 29.10 & 24.90 & 28.40 & 23.60 \\
\hline $\mathrm{Rh}$ & 4.06 & 4.88 & 3.76 & 4.02 & 3.21 \\
\hline $\mathrm{Pt}$ & 0.60 & 1.72 & 0.98 & 1.10 & 0.89 \\
\hline $\mathrm{Pd}$ & 1.00 & 1.18 & 1.12 & 0.87 & 0.91 \\
\hline $\mathrm{Au}$ & 0.50 & 0.56 & 0.61 & 0.48 & 0.50 \\
\hline$\Sigma$ PGE & 48.9 & 57.88 & 51.79 & 57.28 & 43.15 \\
\hline $\mathrm{Pd} / \mathrm{Ir}$ & 0.159 & 0.115 & 0.127 & 0.088 & 0.157 \\
\hline PPGE/IPGE & 0.131 & 0.155 & 0.128 & 0.117 & 0.131 \\
\hline
\end{tabular}

PPGE $=(\mathrm{Rh}+\mathrm{Pt}+\mathrm{Pd}) ; \mathrm{IPGE}=(\mathrm{Os}+\mathrm{Ir}+\mathrm{Ru})$. Sample labels and abbreviations as in Table 1. See captions to Figure 10 for the source of data.

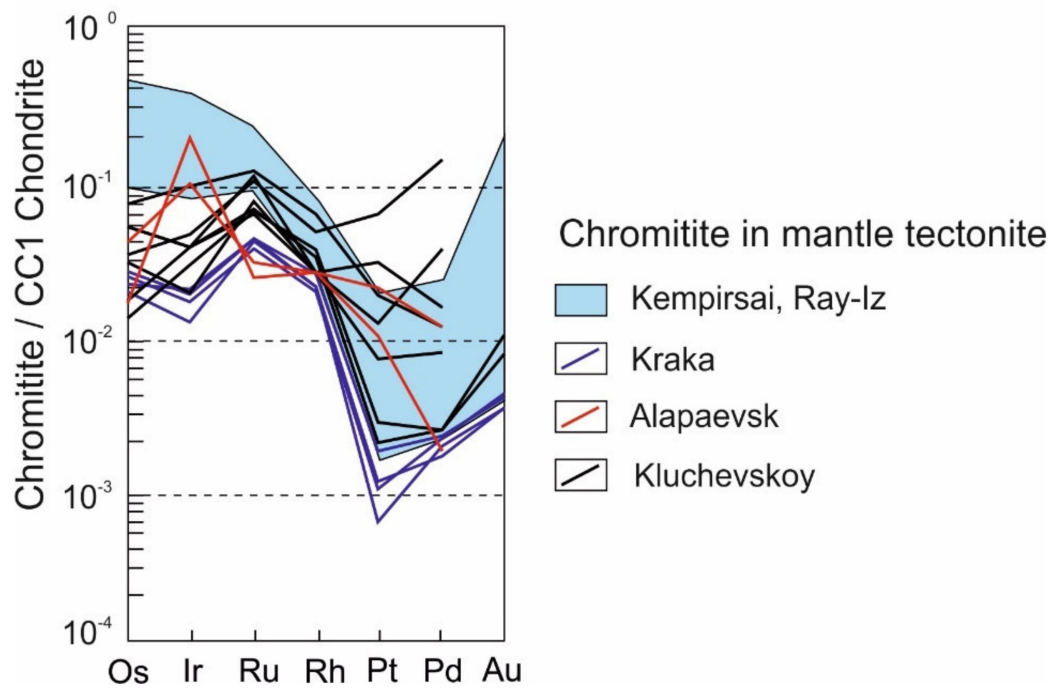

Figure 10. Platinum-group element (PGE) chondrite-normalized patterns for chromite deposits in the mantle tectonite of ophiolite complexes of the Urals (data source [25,48]). CC1 normalization data from [46].

\subsection{PGM Mineralogy and Composition}

Several tens of PGM grains were found in 16 polished sections from the Kraka chromite deposits. They are Ru-Os-Ir phases occurring into two distinct populations: "primary," crystallized at high temperatures, and "secondary," involved in low-temperature alteration processes. Polygonal morphology and inclusion in fresh chromite characterize the primary PGM, supporting that they may have been early solid particles trapped in the chromite that precipitate at high temperatures.

Occasionally, primary magmatic PGM may associate with secondary paragenetic assemblages, as relics preserved by alteration. In contrast, the secondary PGM occur as irregular grains or blebby particles associated with alteration minerals (ferrian-chromite, awaruite, serpentine, chlorite, garnet). They are usually located along cracks or in the 
altered silicate matrix, and are considered to have formed at low-temperature during serpentinization and weathering.

Laurite is the most abundant primary PGM in both deposits. Compositions show significant substitution of $\mathrm{Os}$, Ir, and minor amounts of Rh and Pd (Table 7). Trace amounts of As may substitute for sulfur, whereas variable concentrations of $\mathrm{Cr}$ and Fe detected in the analysis of the smallest grains were ascribed to spurious fluorescence from the enclosing chromite.

Table 7. Electron microprobe analyses (wt \%) of platinum-group minerals (PGM) in podiform chromitite of the Kraka mantle tectonite.

\begin{tabular}{|c|c|c|c|c|c|c|c|c|c|c|c|c|c|}
\hline Sample Label & Mineral & Os & Ir & $\mathbf{R u}$ & $\mathbf{R h}$ & $\mathrm{Pt}$ & Pd & $\mathrm{Fe}$ & $\mathrm{Ni}$ & $\mathrm{Cu}$ & $\mathrm{S}$ & As & Total \\
\hline \multicolumn{14}{|c|}{ Sulfides of the laurite-erlichmanite series } \\
\hline BB Y & Laurite & 14.26 & 6.61 & 39.13 & 0.83 & & 0.57 & & & 0.08 & 36.54 & 0.99 & 99.01 \\
\hline BB Y & Laurite & 16.40 & 6.15 & 41.65 & 0.12 & & & 0.20 & 0.24 & 0.02 & 34.87 & & 99.65 \\
\hline BB7617 1 & Laurite & 27.90 & 2.32 & 31.89 & 0.56 & & 0.40 & 1.33 & 0.04 & 0.07 & 32.83 & 0.52 & 97.86 \\
\hline BB7617 1a 1 & Laurite & 28.97 & 3.99 & 33.86 & & & & 0.13 & 0.13 & & 31.42 & & 98.50 \\
\hline BB7617 1a 1 & Laurite & 26.71 & 2.22 & 30.53 & 0.53 & 0.00 & 0.38 & 1.27 & 0.04 & 0.07 & 31.43 & 0.49 & 93.68 \\
\hline BB7617 1a 2 & Laurite & 28.98 & 4.15 & 35.35 & & & & 0.05 & 0.18 & & 31.34 & & 100.05 \\
\hline BB7617 1b 1 & Laurite & 18.85 & 13.48 & 31.82 & 2.12 & & 0.05 & 0.00 & 0.25 & 0.20 & 32.89 & 0.03 & 99.69 \\
\hline BB7617 1b 1 * & Laurite & 16.88 & 12.73 & 29.63 & 2.48 & 0.00 & 0.82 & 1.84 & 0.17 & 0.47 & 33.27 & 1.70 & 100.00 \\
\hline BB7617 2 & Laurite & 16.34 & 12.32 & 28.69 & 2.40 & & 0.79 & 1.78 & 0.17 & 0.46 & 32.21 & 1.65 & 96.81 \\
\hline BB7617 3 & Laurite & 28.96 & 3.99 & 33.86 & & & & 0.13 & 0.13 & & 31.42 & 0.91 & 99.40 \\
\hline BB7617 4 & Laurite & 28.10 & 3.14 & 35.00 & & & & 0.05 & 0.17 & & 31.30 & 0.50 & 98.26 \\
\hline BB7617 5 & Laurite & 18.85 & 13.48 & 31.82 & 2.12 & & 0.05 & & 0.24 & 0.20 & 32.89 & 0.05 & 99.70 \\
\hline BB7618 1 & Laurite & 13.28 & 6.66 & 44.25 & 0.00 & & 0.00 & 0.12 & 0.21 & 0.10 & 33.81 & 0.06 & 98.49 \\
\hline BB7618 11 * & Laurite & 14.50 & 6.76 & 44.96 & 0.00 & 0.00 & 0.00 & 0.12 & 0.22 & 0.11 & 33.33 & 0.00 & 100.00 \\
\hline BB7618 1a 1 * & Laurite & 12.14 & 5.63 & 33.31 & 0.72 & 0.00 & 0.49 & 15.25 & 0.12 & 0.40 & 31.09 & 0.84 & 100.00 \\
\hline BB7618 2 & Laurite & 14.48 & 6.16 & 39.82 & 0.85 & & 0.73 & 1.28 & 0.01 & 0.29 & 34.19 & 0.15 & 97.96 \\
\hline BB7618 21 & Laurite & 16.40 & 6.15 & 41.65 & 0.12 & & & 0.20 & 0.25 & 0.03 & 34.87 & & 99.68 \\
\hline BB7618 2a 1 & Laurite & 13.68 & 4.59 & 37.07 & 0.86 & 0.00 & 0.54 & 1.58 & 0.08 & 0.12 & 32.59 & 0.91 & 92.02 \\
\hline BB76183 & Laurite & 14.57 & 4.89 & 39.48 & 0.92 & & 0.58 & 1.08 & 0.07 & 0.13 & 34.70 & 0.95 & 97.37 \\
\hline BB7618 4 & Laurite & 16.40 & 6.14 & 41.65 & 0.12 & & & 0.20 & 0.24 & 0.02 & 34.87 & & 99.64 \\
\hline BB7619 1 & Laurite & 13.31 & 7.18 & 40.13 & 0.89 & & 0.59 & 1.70 & 0.07 & 0.12 & 34.50 & 0.69 & 99.18 \\
\hline BB7619 11 & Laurite & 15.76 & 7.34 & 39.04 & 0.28 & & & 0.15 & 0.35 & 0.08 & 33.09 & & 96.10 \\
\hline BB7619 1a 1 * & Laurite & 12.52 & 6.75 & 37.76 & 0.84 & 0.00 & 0.56 & 3.83 & 0.80 & 0.13 & 35.71 & 1.11 & 100.00 \\
\hline BB7619 1a 2 * & Laurite & 13.12 & 6.63 & 38.71 & 0.65 & 0.00 & 0.51 & 3.41 & 0.84 & 0.16 & 35.00 & 0.97 & 100.00 \\
\hline BB7619 2 & Laurite & 14.02 & 7.08 & 41.38 & 0.70 & & 0.55 & 1.51 & 0.11 & 0.15 & 34.03 & 0.94 & 100.47 \\
\hline BB7619 4 & Laurite & 15.76 & 7.34 & 39.04 & 0.27 & & & 0.15 & 0.35 & 0.08 & 33.09 & & 96.08 \\
\hline BB7618 1a 2 * & Laurite & 13.29 & 5.65 & 36.55 & 0.78 & 0.00 & 0.67 & 9.12 & 0.13 & 0.32 & 32.67 & 0.80 & 100.00 \\
\hline PE1754a 1 & Laurite & 7.79 & 3.66 & 37.63 & 12.28 & & 0.42 & & & & 33.70 & 1.26 & 96.74 \\
\hline PE1754a 2 & Laurite & 17.61 & 4.46 & 40.53 & 0.26 & & 0.42 & & & & 33.28 & 0.50 & 97.06 \\
\hline PE1758a 1 & Laurite & 5.88 & 14.57 & 38.56 & 1.25 & & 0.72 & & & & 32.68 & 2.74 & 96.40 \\
\hline PE1758a 2 & Laurite & 5.42 & 14.83 & 38.98 & 1.50 & & 0.30 & & & & 32.49 & 2.71 & 96.23 \\
\hline PE1758a 3 & Laurite & 5.56 & 14.64 & 39.35 & 1.27 & & 0.49 & & & & 32.24 & 2.57 & 96.12 \\
\hline PE1759* & Laurite & 29.09 & 4.76 & 24.78 & 0.00 & 0.00 & 0.00 & 1.72 & 0.60 & 4.80 & 33.01 & 1.24 & 100.00 \\
\hline PE1759* & Laurite & 32.13 & 5.17 & 27.71 & 0.00 & 0.00 & 0.00 & 0.75 & 0.00 & 1.03 & 33.20 & 0.00 & 100.00 \\
\hline PE1757 1 & Erlichmanite & 34.97 & 15.94 & 17.72 & 0.84 & & 0.38 & & & & 27.47 & 1.08 & 98.40 \\
\hline \multicolumn{14}{|c|}{ Primary and secondary sulfides and arsenides } \\
\hline PE1759* & Un. $(\mathrm{NiFePt})_{9} \mathrm{~S}_{8}$ & 0.00 & 0.00 & 0.00 & 0.00 & 1.09 & 0.00 & 3.63 & 61.96 & 0.00 & 33.32 & 0.00 & 100.00 \\
\hline BB7619 3 & Ru-pentlandite & 3.61 & 1.42 & 8.48 & 0.29 & 0.12 & & 11.78 & 42.28 & 0.17 & 31.95 & 0.15 & 100.25 \\
\hline BB7619 $3 *$ & Ru-pentlandite & 3.68 & 1.45 & 9.65 & 0.30 & 0.13 & 0.00 & 8.94 & 43.01 & 0.18 & 32.50 & 0.16 & 100.00 \\
\hline PE1755 * & Un. $\mathrm{Ni}_{3} \mathrm{As}$ & 0.00 & 11.45 & 1.92 & 5.06 & 0.00 & 0.00 & 0.00 & 55.34 & 0.00 & 0.00 & 26.22 & 100.00 \\
\hline \multicolumn{14}{|c|}{ Primary and secondary alloys } \\
\hline PE1757b 1 & Rutheniridosmine & 44.01 & 4.64 & 47.68 & 0.00 & & & & & & 0.00 & 0.29 & 96.62 \\
\hline PE1757b 2 & Rutheniridosmine & 44.04 & 5.40 & 47.84 & 0.00 & & & & & & 0.00 & 0.19 & 97.47 \\
\hline PE1755* & Ruteniridosmine & 55.19 & 14.18 & 22.37 & 0.00 & 0.00 & 0.00 & 2.94 & 5.32 & 0.00 & 0.00 & 0.00 & 100.00 \\
\hline PE1755* & Ruthenium & 0.00 & 10.47 & 60.34 & 0.00 & 0.00 & 0.00 & 9.18 & 20.01 & 0.00 & 0.00 & 0.00 & 100.00 \\
\hline $\mathrm{BB} X$ & Awaruite & & 0.39 & & 0.22 & 0.46 & & 25.25 & 71.01 & & 0.09 & 0.38 & 97.80 \\
\hline PE1755 * & Garutiite & 0.00 & 39.73 & 0.00 & 0.00 & 0.00 & 0.00 & 3.75 & 53.84 & 2.69 & 0.00 & 0.00 & 100.00 \\
\hline
\end{tabular}

$\mathrm{BB}=$ Southern Kraka (Bolshoi Bashart mine). PE = Middle Kraka (Deposit 33). $\left({ }^{*}\right)$ normalized EDS analysis. Un. $=$ unidentified phase.

In the $\mathrm{BB}$ deposit, laurite occurs as idiomorphic crystals systematically in contact with pyroxene (Figure 11A-C), between the $\left(\mathrm{Ru}_{0.84} \mathrm{Os}_{0.14} \mathrm{Ir}_{0.07}\right)_{1.05} \mathrm{~S}_{1.95}$ and $\left(\mathrm{Ru}_{0.62} \mathrm{Os}_{0.19} \mathrm{Ir}_{0.13} \mathrm{Rh}_{0.04}\right)_{0.99} \mathrm{~S}_{2.01}$ in composition - the latter approaches the chondrite atomic ratio $\mathrm{Ru} / \mathrm{Os}$. Only one grain 
(BB7619-1) with composition $\left(\mathrm{Ru}_{0.75} \mathrm{Os}_{0.16} \mathrm{Ir}_{0.07} \mathrm{Rh}_{0.01}\right)_{0.99} \mathrm{~S}_{2.01}$ was found intergrown with Ti-rich amphibole and a $\left(\mathrm{Ru}_{1.1} \mathrm{Fe}_{1.4} \mathrm{Ni}_{6.2}\right)_{8.7} \mathrm{~S}_{8.3}$ sulfide, possibly Ru-pentlandite (Figure 11D).
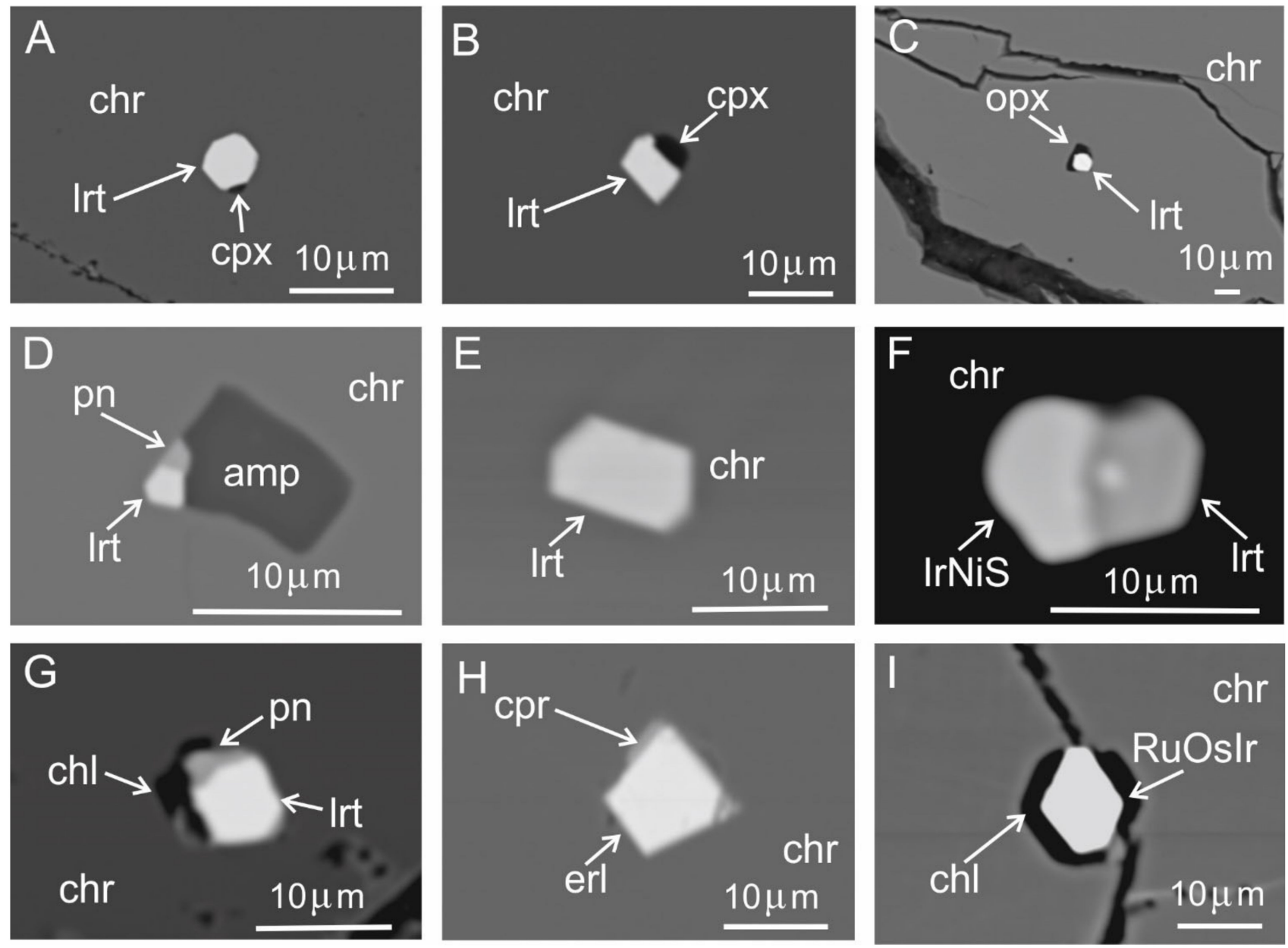

Figure 11. BSE images of primary PGM inclusions in chromite from the deposits of Kraka. Laurite + clinopyroxene, samples BB7617 (A), BB7671 (B); laurite + orthopyroxene, sample BB7618 (C); laurite + pentlandite + amphibole, sample BB7619 (D); laurite, sample PE1758 (E); laurite + Ir-Ni sulfide, sample PE1754a, (F); laurite + pentlandite + chlorite, sample PE1752 (G); erlichmanite + cuproiridsite, sample PE1757a (H); Ru-Os-Ir alloy + clinopyroxene + chlorite, sample PE1757b (I). Abbreviations: $\mathrm{chr}=$ chromite; $\mathrm{cpx}=$ clinopyroxene; $\mathrm{opx}=$ orthopyroxene; $\mathrm{amp}=$ amphibole; $1 \mathrm{rt}=$ laurite; $\mathrm{cpr}=\mathrm{cuproiridsite;}$ IrNiS = unnamed Ir-Ni sulfide; pn = pentlandite; erl = erlichmanite. Sample BB = Bolshoi Bashart; sample PE = Prospect 33.

Unlike BB, laurite from Prospect 33 is accompanied by primary PGE alloys in the Os$\mathrm{Ru}$-Ir system (ruthenium, osmium): erlichmanite $\left(\mathrm{OsS}_{2}\right)$, cuproiridsite $\left(\mathrm{CuIr}_{2} \mathrm{~S}_{4}\right)$, an unidentified Ir-Rh-Ni sulfide, and PGE-bearing Ni sulfides (Ru-pentlandite). Laurite and erlichmanite may occur as isolated euhedral crystals inside chromite grains (Figure 11E), whereas the associated sulfides are attached to laurite and erlichmanite crystals (Figure 11F-H), suggesting epitaxic overgrowth at high temperature. The composition of laurite extends from $\left(\mathrm{Ru}_{0.74} \mathrm{Os}_{0.06} \mathrm{Ir}_{0.14} \mathrm{Rh}_{0.02} \mathrm{Pd}_{0.08}\right)_{1.04}\left(\mathrm{~S}_{1.90} \mathrm{As}_{0.06}\right)_{1.96}$ to $\left(\mathrm{Ru}_{0.55} \mathrm{Os}_{0.34} \mathrm{Ir}_{0.05}\right)_{0.94} \mathrm{~S}_{2.06}$, below the chondritic ratio, and enters the field of erlichmanite $\left(\mathrm{Os}_{0.41} \mathrm{Ru}_{0.39} \mathrm{Ir}_{0.19} \mathrm{Rh}_{0.02} \mathrm{Pd}_{0.04}\right)_{1.05}\left(\mathrm{~S}_{1.92} \mathrm{As}_{0.03}\right)_{1.95}$ (Figure 12). Primary alloys in the Ru-Os-Ir system (ruthenium $\mathrm{Ru}_{62.7} \mathrm{Os}_{28.7} \mathrm{Ir}_{3.2} \mathrm{Pd}_{5.4}$, and osmium $\mathrm{Os}_{50} \mathrm{Ru}_{38} \mathrm{Ir}_{12}$ ) usually have the euhedral morphology typical of primary PGM crystallized at a high temperature (Figure 11I), and may have an unfractionated composition close to the $\mathrm{Ru} /$ Os chondritic ratio (Figure 12). 


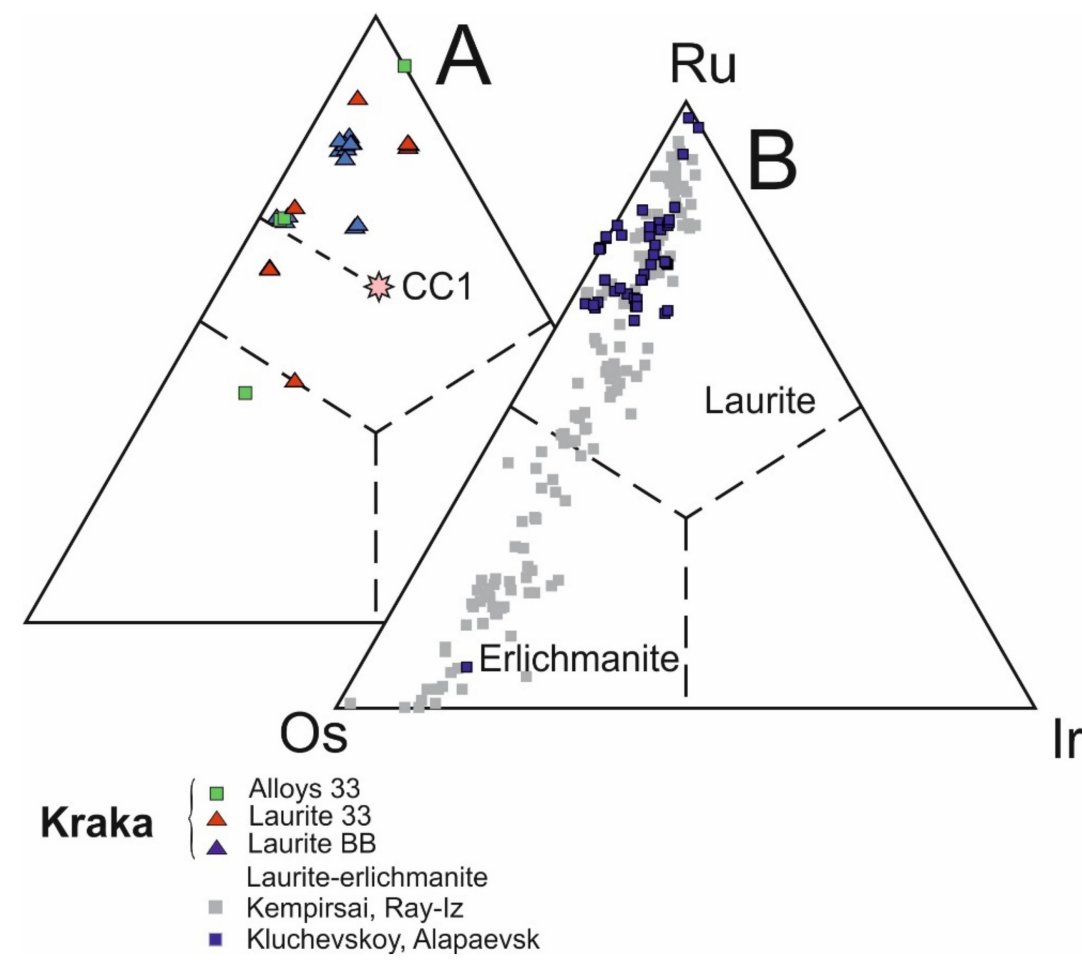

Figure 12. Compositions of laurite-erlichmanite sulfides and Ru-Os-Ir alloys from the chromite deposits of Kraka (A). Composition of laurite-erlichmanite sulfides from the chromite deposits of Ray-Iz, Kempirsai, gray squares; Kluchevskoy, Alapaevsk, blue squares (B) (data source [25,27,28,43]).

\subsection{Origin of Primary PGM as a Function of $f\left(S_{2}\right)$}

The paragenesis and composition of the magmatic PGM can be modeled according to a sequence of crystallization events controlled by relative stability of PGE alloys and sulfides as a function of sulfur fugacity, $f\left(S_{2}\right)$, and temperature, $T{ }^{\circ} \mathrm{C}$. The $f\left(S_{2}\right)$ increases with decreasing $\mathrm{T}$ in magmatic systems, and the $\mathrm{Ru}$, Ir, and Os sulfides become progressively stable over a range of about four $\log$ units in $\mathrm{f}\left(\mathrm{S}_{2}\right)$ at a given temperature, or in a thermal interval between $300{ }^{\circ} \mathrm{C}$ and $400{ }^{\circ} \mathrm{C}$ at a constant $\mathrm{f}(\mathrm{S} 2)$. Therefore, the final paragenesis (sulfides versus alloys) is controlled by the initial $\mathrm{f}(\mathrm{S} 2)$, and the timing of chromite crystallization, which represents the closure of the system in which PGM inclusions precipitated. Epitaxic overgrowth of both Ir-thiospinels and Ir-Rh-Ni sulphides on laurite and erlichmanite indicates that there is a crystallization order of primary PGM controlled by relative stability of PGE alloys and sulfides as function of $f\left(S_{2}\right)$ increasing at decreasing temperature (Figure 13). Assuming that the PGE occur as atomic clusters suspended in mafic magmas, the refractory Ru alloy (ruthenium) and Ru sulfide (laurite) could crystallize directly from the liquid at temperatures as high as $1300-1250{ }^{\circ} \mathrm{C}$, and at sulfur fugacity $\left(\log f\left(\mathrm{~S}_{2}\right)=-3.0\right)$ well below the sulfide-saturation threshold [49]. The PGM paragenesis in the deposit 33 indicates that the system moved to higher $f\left(\mathrm{~S}_{2}\right)$, enabling precipitation of Os-rich laurite and erlichmanite, followed by cuproiridsite and Ir-Ni sulfides. The buffers $\mathrm{Ni}_{3} \mathrm{~S}_{2}-\mathrm{NiS}$ and $\mathrm{Os}-\mathrm{OsS}_{2}$ cut into each other at about $1050{ }^{\circ} \mathrm{C}$ and $650{ }^{\circ} \mathrm{C}$ (Figure 13); thus, the precipitation of millerite (NiS monosulfide) marks the achievement of the highest sulfur fugacity $\left(\log f\left(\mathrm{~S}_{2}\right)=-1.0\right)$ in deposit 33 .

In the BB deposit, Laurite was the only pristine liquidus phase supporting that the initial sulfur fugacity did not increase enough to stabilize Os-rich laurite, erlichmanite, and the Ir sulfides. Only occasional crystallization of Ru-pentlandite (ideal $\left.(\mathrm{Ni}, \mathrm{Fe}, \mathrm{Ru})_{9} \mathrm{~S}_{8}\right)$ was observed to occur in equilibrium with Os-poor laurite. The paragenetic assemblages of the primary PGM inclusions require that the sequence of crystallization took place according to different trends of $f\left(\mathrm{~S}_{2}\right)-\mathrm{T}^{\circ} \mathrm{C}$ in the Kraka deposits (Figure 13). 


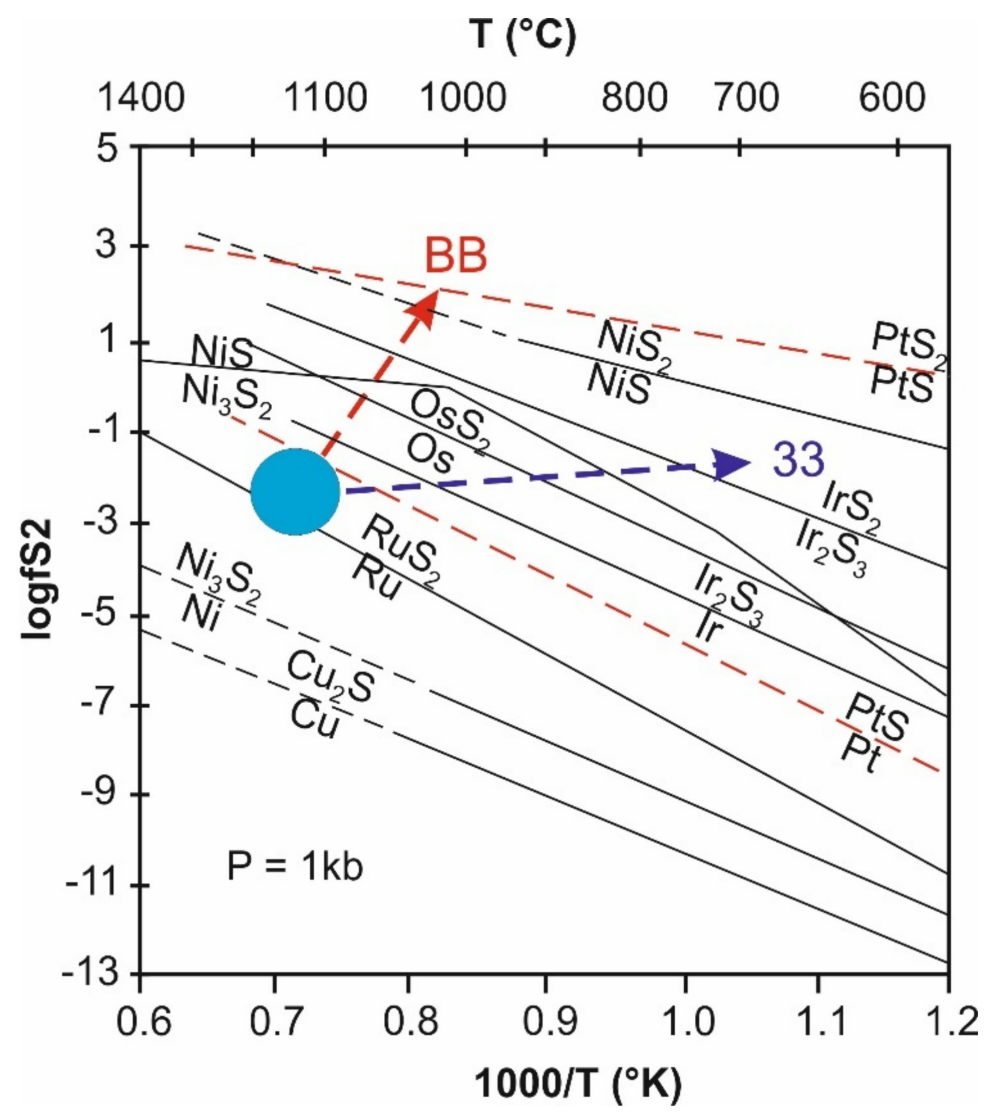

Figure 13. Metal-sulfide reaction lines for PGE ( $\mathrm{Ru}, \mathrm{Os}, \mathrm{Ir}, \mathrm{Pt})$ and base metals $(\mathrm{Cu}, \mathrm{Ni})$ as functions of temperature and sulfur fugacity. The arrows show the different variation paths of $\mathrm{T}{ }^{\circ} \mathrm{C}-\log \left(\mathrm{S}_{2}\right)$ determined by the different cooling rate, resulting in the stabilization of Laurite $\left(\mathrm{RuS}_{2}\right)$ in deposit BB, and laurite + erlichmanite $\left(\mathrm{OsS}_{2}\right)+\left(\mathrm{IrS}_{2}\right)$ in deposit 33 (modified after [9]).

\subsection{PGM Reworking at Low Temperature}

Due to their textural position, the PGM not included in chromite were exposed to alteration and underwent alteration and remobilized at a small scale by the action of low-temperatures fluids. A common alteration process that has been observed in Kraka and many other ophiolitic chromitites elsewhere is the progressive removal of sulfur (desulfurization) from magmatic laurite, followed by oxidation that results in the formation of complex intergrowths between ruthenium, magnetite, and Fe-hydroxides that were initially interpreted a result of direct oxidation of the PGE, although PGE-O chemical bonds could not be ascertained [24,50-52].

During this process, laurite may release Os and Ir that are incorporated in secondary Os-Ir alloys, frequently intergrown with Fe-oxide-hydroxide phases [53]. At Kraka, the secondary PGE alloys that probably derived from reductions of primary Ni-Fe-PGE sulfides consist of Os-Ru-Ir-Ni-Fe compounds and garutiite $\left(\mathrm{Ni}_{1.49} \mathrm{Fe}_{0.11} \mathrm{Cu}_{0.07}\right)_{1.67} \mathrm{Ir}_{0.33}$.

The Os-Ir-Ru alloys form small droplets at the border of secondary awaruite and heazlewoodite in contact with ferrian-chromite and serpentine (Figure 14A) or chlorite (Figure 14B), suggesting an origin by alteration of a magmatic sulfide precursor during serpentinization at temperatures below $400{ }^{\circ} \mathrm{C}$. Garutiite is included in the chlorite matrix (Figure 14C) possibly precipitated during low temperature alteration of the chromitite, as proposed for garutiite in the Loma Peguera type locality [54]. The recently re-validated, dienerite $\mathrm{Ni}_{3} \mathrm{As}$ [55] fills cracks in the chromite (Figure 14D) and other secondary Niarsenides sometimes associated with garutiite appear to have deposited at low temperature by hydrous solution charged with As and remobilized Ni and PGE. 

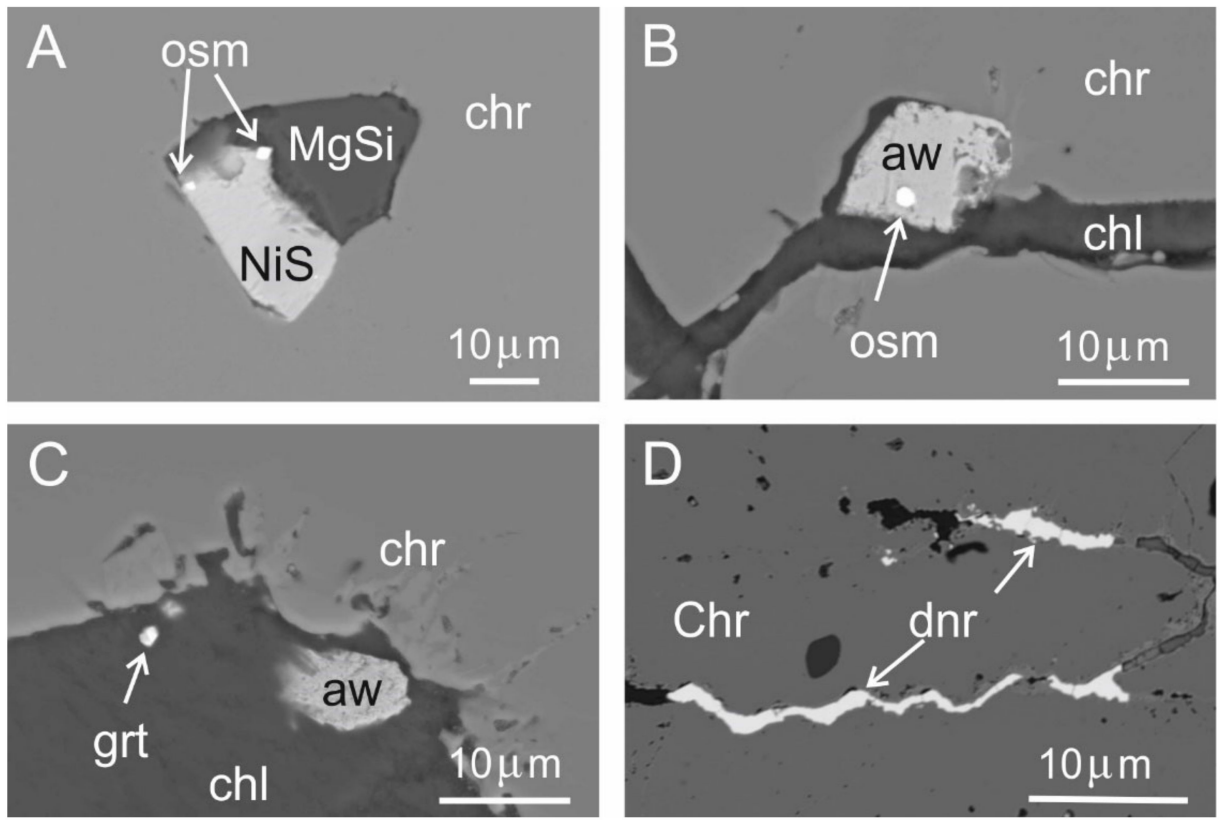

Figure 14. BSE images of primary PGM inclusions in chromite from the deposits of Kraka. Native Os + millerite + serpentine, sample PE1759 (A); native Os + awaruite (B); garutiite + Ni-arsenide in the altered chlorite matrix, sample PE1755 (C); dienerite filling fissures in chromite, sample PE1755 (D). Abbreviations: osm = native osmium; chr = chromite; $\mathrm{MgSi}=$ serpentine; $\mathrm{chl}$ = chlorite; aw = awaruite; grt = garutiite; $\mathrm{dnr}=$ dienerite .

\section{Discussion}

The spreading rate of the oceanic crust may control the thickness of the lithosphere, i.e., a high spreading rate generates a thin lithosphere and slow spreading produces a thick lithosphere [2]. Therefore, huge chromite deposits are rarely hosted in LOT, compared to the more depleted HOT in which numerous and larger chromite deposits may occur [2]. Another model implies that the abundance of chromitites is related to the nature of the rising mantle, particularly if it is fertile or already depleted [2]. As a consequence, the formation of chromitites in ophiolites is indirectly related to spreading rate, controlling mantle fertility and depth of melt crystallization. Giant chromite deposits are related to ophiolites characterized by a low to intermediate spreading rate and a fertile source [2]. According to this model, the podiform chromites hosted in the Kraka mantle tectonite of a LOT cannot compete with the giant deposits of the Urals (Kempirsai, Ray-Iz) for the amount of chromite reserve and the variety of PGM species associated with chromitite. These world-class deposits are typically hosted in subduction-related HOT mantle tectonite of the Urals, where geodynamic conditions favored multi-stage melting processes that generated boninite-type magmas enriched in $\mathrm{Cr}$ and PGE [56].

In addition to mantle fertility and melt supply, a further factor controlling the precipitation of large bodies of chromitites is the presence of metasomatic fluids [2,9]. Therefore, the absence of giant chromite deposits suggests that the Kraka chromitite suffered the effects of the metasomatism to a lesser extent compared with Kempirsai and Ray-Iz chromitites. Prolonged draining of large amounts of boninite caused remobilization, redistribution, and concentration of $\mathrm{Cr}$ in ore bodies of various sizes within the upper mantle section [57]. Primary magmatic PGM included in chromite show general predominance of Ru-Os-Ir sulfide species $[9,25,28,43]$. This supports that the chromitite parent melt was carrying significant amounts of dissolved sulfide at the time of its emplacement, although the bulk S concentration never exceeded the saturation threshold. The relatively high "sulfide capacity" of the melt increased its ability to dissolve PGE during reaction with the country rock residual mantle, thereby enabling high concentrations of PGE in the boninite magma. Segregation of PGM from the mafic melt started in the high-temperature orthomagmatic stage, and due 
to the relatively high fluid activity, lasted below the solidus of chromite at temperatures as low as $700{ }^{\circ} \mathrm{C}$. If PGE clusters were still present in solid chromite, they could easily convert into discrete PGM inclusions splitting off the chromite during re-crystallization adjustment of its composition on cooling [28]. Variations in S and As fugacity $f\left(S_{2}\right)$ with temperature must have controlled the relative stability of mineral species, alloys versus sulfides, and arsenides.

Formation of the giant chromite deposits that typify the Ural Chromite Province appears to be restricted to large ophiolite blocks exposed in the Polar and Southern Urals that represent sub-oceanic lithosphere flooring the western sector of the Uralian Ocean [34]. In this region, intra-oceanic thrust and subduction zones developed in the LateOrdovician/Lower-Silurian, causing deep metasomatism of the upper mantle wedge and the formation of giant orebodies of chromite up to the Low and Middle Devonian. These processes do not appear to have taken place elsewhere in the Urals, and probably correspond to the paroxysmic peak of the geodynamic convergence that led to plate collision and obduction of oceanic crust onto the European continental margin (Carboniferous-Permian).

Likewise, Kempirsai, the Kraka ophiolite, is located in the Southern Urals, to the West of the suture zone. However, the petrologic nature (LOT mantle tectonite) and the original geodynamic setting, a possible continental margin as defined by [17], differ remarkably from those expected in a typical SSZ. There is no evidence for an important subduction event in the lherzolite mantle tectonite of Kraka, and geodynamic conditions suitable for the formation of large chromite deposits were never reached. The podiform chromitites of Kraka were formed by one single event of partial melting, and a reaction of poorly depleted lherzolite with a small volume of magma-relatively "dry" (poor in hydrous fluids) compared with "boninite," and not particularly enriched in Cr, PGE, or sulfides. The chemical disequilibrium necessary to trigger intensive mantle/melt metasomatic reaction was insufficient, and precipitation of chromite was limited in space and time, giving rise to small size deposits [14]. The mantle/crust transition of Kraka resembles that of the so-called root ophiolites (Nurali, Mindyak) exposed along the suture zone, south of Miass (latitude $55^{\circ} \mathrm{N}$ ). These ophiolites do not contain significant chromite deposits in the mantle section, although similarly to Kraka, they host veins and thin layers of Al-Fe rich chromite with Pt mineralization, in the supra-Moho cumulus wehrlite, clinopyroxenite [13].

\section{Summary and Conclusions}

1. The studied podiform chromite deposits of the Kraka lherzolite massif occur in two distinct positions of the mantle stratigraphy: the shallow one $(\mathrm{BB})$ is located in a harzburgite horizon, just below the mantle/crust transition zone; the other (Prospect 33) is seated deep in the mantle tectonite. Both deposits consist of highCr chromitite $(\mathrm{Cr} \#=0.70-0.83$ ) similar to boninite-derived chromitites in ophiolite complexes, and are surrounded by a dunite envelope, indicating a reaction between wall-rock residual mantle and adiabatically ascending melts ([14] and references therein). The chromite/olivine equilibrium reflects a rapid cooling rate in the shallow deposit $\left(\mathrm{T}=1300-1100^{\circ} \mathrm{C}\right)$ that did not enable an increase in sulfur fugacity above $\log f S_{2}=-3.0$, yielding very limited Ru-Os PGM mineralization (mainly laurite). In the deep-seated deposit, a slow cooling rate allowed closure of the chromite crystallization system between $1100^{\circ} \mathrm{C}$ and $800^{\circ} \mathrm{C}$, and slightly higher sulfur fugacity, $\log f\left(\mathrm{~S}_{2}\right)>+1.0$, could developed, producing a more complex assemblage of laurite, erlichmanite, and Ir sulfides now occurring as inclusions in chromite crystals.

2. The chondrite-normalized PGE patterns of the Bolshoi Bashart chromitite overlap in terms of chondritic abundance and the distribution of PGE in chromitites from the Alapaevsk and Kluchevskoy ophiolite massifs, now exposed the East-Uralian zone (Figure 1B). This zone is the easternmost region of the Urals that contains ophiolite blocks with chromite deposits, usually intermixed with granites and fragments of continental crust that may indicate a paleogeographic location proximal to a continental block in the eastern side of the Uralian Ocean [8,34]. 
3. In contrast with the large ophiolite complexes of the western Uralian basin hosted in the HOT ophiolites, the mantle tectonite such as Kraka, of the LOT ophiolite contains only small and medium-size deposits of high-Cr chromitite with a minor transition to high-Al ore. Ages dating back to Precambrian have been proposed for accretion of the suboceanic lithosphere at Alapaevsk [27], possibly indicating that intensive intra-oceanic thrusts and subduction did not start yet in this epoch in this part of the basin. The fact that the chromitites contain only laurite-type mineralization, similarly to Kraka, is a clear indication of low sulfur fugacity and fluid depleted composition of the percolating melts [12]. Therefore, deep mantle metasomatism responsible for the formation of the giant deposits of the Urals (Kempirsai, Ray-Iz) was hampered. The occurrence of the high-Cr deposit inside lherzolite type mantle tectonite remains a quite isolated case in the Urals, possible representing a case of chromitite probably associated with a continental margin type ophiolite.

Author Contributions: G.G. wrote the article. All the authors revised the paper, conceived the experiments, and provided contributions to the data interpretation. The field work and preliminary studying of samples were carried out by E.V.P., I.A.G. and F.Z. conducted the WDS analyses. All authors have read and agreed to the published version of the manuscript.

Funding: This research received no external funding.

Acknowledgments: The authors acknowledge the University Centrum for Applied Geosciences (UCAG) for the access to the E. F. Stumpfl electron microprobe laboratory. This study was supported by Russian State scientific program AAAA-A18-118052590029-6. Many thanks are due to the referees for their useful remarks and comments that improved our manuscript. We are grateful to the handling editors, and to the members of the editorial staff for their constructive suggestions.

Conflicts of Interest: The authors declare no conflict of interest.

\section{References}

1. Koroteev, V.A.; De Boorder, H.; Necheukhin, V.M.; Sazonov, V.N. Geodynamic setting of the mineral deposits of the Urals. Tectonophysics 1997, 276, 291-300. [CrossRef]

2. Boudier, F.; Al-Rajhi, A. Structural control on chromite deposits in ophiolites: The Oman case. In Tectonic Evolution of the Oman Mountain; Special Publications; Rollinson, H.R., Searle, M.P., Abbasi, I.A., Al-Lazki, A., Al Kindi, M.H., Eds.; The Geological Society of London: London, UK, 2014; Volume 392, pp. 259-273.

3. Khedr, M.Z.; Arai, S. Chemical variations of mineral inclusions in Neoproterozoic high-Cr chromitites from Egypt: Evidence of fluids during chromitite genesis. Lithos 2016, 240-243, 309-326. [CrossRef]

4. Kravchenko, G.G. The Urals chromite deposits. In Metallogeny of Basic and Ultrabasic Rocks (Regional Presentation); Carter, B., Ed.; Theophrastus Publications: Athens, Greece, 1986; pp. 179-187.

5. Kravchenko, G.G. Geological position and structure of chromite deposits in the Ural mountains. In Chromitites, UNESCO's IGCP-197 Project, Metallogeny of Ophiolites; Petrascheck, W., Ed.; Theophrastus Publications: Athens, Greece, 1986 ; pp. 3-21.

6. Kravchenko, G.G.; Grigoryeva, I.I. The Kempirsai chromite-bearing massif in the Ural mountains. In Chromitites, UNESCO's IGCP-197 Project, Metallogeny of Ophiolites; Petrascheck, W., Ed.; Theophrastus Publications: Athens, Greece, 1986 ; pp. 23-44.

7. Nicolas, A.; Boudier, F. Textural insights on significance of ophiolitic chromitites, with special reference to Oman. Acta Geol. Sin. 2020, 94, 4. [CrossRef]

8. Saveliev, A.A.; Savelieva, G.N. The ophiolites of the Kempirsai massif: Basic features of their structural and compositional evolution. Geotectonics 1991, 15, 498-511.

9. Melcher, F.; Grum, W.; Simon, G.; Thalhammer, T.V.; Stumpfl, E.F. Petrogenesis of the ophiolitic giant chromite deposits of Kempirsai, Kazakhstan: A study of solid and fluid inclusions in chromite. J. Petrol. 1997, 38, 1419-1458. [CrossRef]

10. Melcher, F.; Grum, W.; Thalhammer, T.V.; Thalhammer, O.A.R. The giant chromite deposits at Kempirsai, Urals: Constraints from trace element (PGE, REE) and isotope data. Mineral. Depos. 1999, 34, 250-272. [CrossRef]

11. Savelieva, G.N. Chromitites of the Polar Urals, Russia. In Proceedings of the 8th ICAM-BR on Applied Mineralogy, Águas de Lindóia, San Paulo, Brazil, 19-22 September 2004; Volume 2, pp. 943-945.

12. Zaccarini, F.; Pushkarev, E.; Garuti, G. Platinum-group element mineralogy and geochemistry of chromitite of the Kluchevskoyoy ophiolite complex, central Urals (Russia). Ore Geol. Rev. 2008, 33, 20-30. [CrossRef]

13. Zaccarini, F.; Pushkarev, E.; Fershtater, G.B.; Garuti, G. Composition and mineralogy of PGE-rich chromitites in the Nurali Lherzolite-gabbro complex, southern Urals, Russia. Can. Mineral. 2004, 42, 545-562. [CrossRef]

14. Garuti, G.; Pushkarev, E.; Thalhammer, O.A.R.; Zaccarini, F. Chromitites of the Urals (Part 1): Overview of chromite mineral chemistry and geo-tectonic setting. Ofioliti 2012, 37, 27-53. 
15. Boudier, F.; Nicolas, A. Harzburgite and lherzolite subtypes in ophiolitic and oceanic environments. Earth Planet. Sci. Lett. 1985, $76,84-92$.

16. Ishiwatari, A. Alpine ophiolites: Product of low degree mantle melting in a Mesozoic transcurrent rift zone. Earth Planet. Sci. Lett. 1985, 76, 93-108. [CrossRef]

17. Nicolas, A. The Various Ophiolites and their Oceanic Environments of Origin. In Structures of Ophiolites and Dynamics of Oceanic Lithosphere; Petrology and Structural Geology; Springer: Dordrecht, The Netherlands, 1989; Volume 4, pp. $187-201$.

18. Arai, S. Origin of podiform chromitites. J. Asian Earth Sci. 1997, 15, 303-310. [CrossRef]

19. Arai, S.; Miura, M. Formation and modification of chromitites in the mantle. Lithos 2016, 264, 277-295. [CrossRef]

20. Zhou, M.-F.; Sun, M.; Keays, R.R.; Kerrich, R.W. Controls on platinum-group elemental distributions of podiform chromitites: A case study of high-Cr and high-Al chromitites from Chinese orogenic belts. Geochimica et Cosmochimica Acta 1998, 62, 677-688. [CrossRef]

21. Rollinson, H.R. Chromite in the mantle section of the Oman ophiolite: A new genetic model. Isl. Arc 2005, 14, 542-550. [CrossRef]

22. Razin, L.V. Geologic and genetic features of forsterite dunites and their platinum-group mineralization. Econ. Geol. 1976, 71, 1371-1376. [CrossRef]

23. Rudashevskiy, N.S. Origin of various types of platinoid mineralization in ultramafic rocks. Int. Geol. Rev. 1987, 29, 465-480. [CrossRef]

24. Garuti, G.; Pushkarev, E.V.; Zaccarini, F. Diversity of chromitite-PGM mineralization in ultramafic complexes of the Urals. Invited talk to CERCAMS-5, IGCP-473 Workshop: Nickel (+PGE) Deposits of Russia. In Proceedings of the Natural History Museum of London, London, UK, 4-5 November 2004. Abstracts 12.

25. Garuti, G.; Zaccarini, F.; Pushkarev, E.; Thalhammer, O. Systematics of Platinum Group Minerals (PGM) in chromitites of the Urals: Implications for the origin of Chromite-PGE mineralisation in the suboceanic lithosphere. In Proceedings of the 13th International Platinum Symposium, Polokwane, South Africa, 30 June-6 July 2008; pp. 43-44.

26. Garuti, G. The chromitite-PGE association of the Urals: An overview. In Proceedings of the 12th International Platinum Symposium, Yekaterinburg, Russia, 11-14 August 2014; pp. 171-172.

27. Zaccarini, F.; Pushkarev, E.V.; Garuti, G.; Kazakov, I. Platinum-Group Minerals and other accessory phases in chromite deposits of the Alapaevsk ophiolite, Central Urals, Russia. Minerals 2016, 6, 108. [CrossRef]

28. Zaccarini, F.; Garuti, G.; Pushkarev, E.; Thalhammer, O. Origin of Platinum Group Minerals (PGM) inclusions in chromitite deposits of the Urals. Minerals 2018, 8, 379. [CrossRef]

29. Saveliev, D.E.; Belogub, E.V.; Zaikov, V.V.; Snachev, V.I.; Kotlyarov, V.A.; Blinov, I.A. First occurrence of PGE mineralization in ultramafic rocks of the Middle Kraka Massif, the Southern Urals. Dokl. Earth Sci. 2015, 460, 103-105. [CrossRef]

30. Savelieva, G.N. Gabbro-Ultramafic Complexes in the Urals and Their Equivalents in the Modern Oceanic Crust; Nauka: Moscow, Russia, 1987; 245p. (In Russian)

31. Saveliev, D.E. Chromitites of the Kraka ophiolite (South Urals, Russia): Geological, mineralogical and structural features. Mineral Depos. 2021, 56, 1111-1132. [CrossRef]

32. Dilek, Y.; Furnes, H. Ophiolite genesis and global tectonics: Geochemical and tectonic fingerprinting of ancient oceanic lithosphere. Geol. Soc. Am. Bull. 2011, 123, 387-411. [CrossRef]

33. Dilek, Y.; Furnes, Y. Origins of ophiolites. Elements 2014, 10, 93-100. [CrossRef]

34. Savelieva, G.N.; Nesbitt, R.W. A synthesis of the stratigraphic and tectonic setting of the Uralian ophiolites. J. Geol. Soc. Lond. 1996, 135, 525-537. [CrossRef]

35. Savelieva, G.N.; Saveliev, A.A. Relationship between peridotites and gabbroic sequences in the ophiolites of the Urals and the lesser Caucasus. Ofioliti 1992, 17, 117-138.

36. Pérez-Estaún, A.; Brown, D. Uralides: A key to understanding collisional orogeny. In Europrobe; Lithosphere Dynamics: Origin and Evolution of Continents; Gee, D.G., Zeyen, H.J., Eds.; Europrobe Secretariate, Uppsala University: Uppsala, Sweden, 1996; pp. 28-39.

37. Fershtater, G.B.; Montero, P.; Borodina, N.S.; Pushkarev, E.V.; Smirnov, V.N.; Bea, F. Uralian magmatism: An overview. Tectonophysics 1997, 276, 87-102. [CrossRef]

38. Fershtater, G.B.; Bea, F.; Borodina, N.S.; Montero, P. Lateral zonation, evolution, and geodynamic interpretation of magmatism of the Urals: New petrological and geochemical data. Petrology 1998, 6, 409-433.

39. Savelieva, G.N.; Sharaskin, A.Y.; Saveliev, A.A.; Spadea, P.; Gaggero, L. Ophiolites of the southern Uralides adjacent to the East European continental margin. Tectonophysics 1997, 276, 117-137. [CrossRef]

40. Fershtater, G.B.; Bea, F. Geochemical typification of Ural ophiolites. Geokhimiya 1996, 3, 195-218. (In Russian)

41. Spadea, P.; D'Antonio, M. Initiation and evolution of intraoceanic subduction in the Uralides: Geochemical and isotopic constraints from Devonian oceanic rocks of the Southern Urals, Russia. Isl. Arc 2006, 15, 7-25. [CrossRef]

42. Ballhaus, C.; Berry, R.F.; Green, D.H. High-pressure experimental calibration of the olivine-orthopyroxene-spinel geobarometer: Implications for the oxidation state of the upper mantle. Contrib. Mineral. Petrol. 1991, 107, 27-40. [CrossRef]

43. Garuti, G.; Zaccarini, F.; Moloshag, V.; Alimov, V. Platinum-group minerals as indicators of sulfur fugacity in ophiolitic upper mantle: An example from chromitites of the Ray-Iz ultramafic complex (Polar Urals, Russia). Can. Mineral. 1999, 37, $1099-1116$.

44. Irvine, T.N. Chromian spinel as a petrogenetic indicator. Part 2. Petrologic applications. Can. J. Earth Sci. 1967, 4, 71-103. [CrossRef] 
45. Roeder, P.L. Chromite: From the fiery rain of chondrules to the Kilauea Iki lava lake. Can. Mineral. 1994, 22, 729-746.

46. Naldrett, A.J.; Duke, J.M. Pt metals in magmatic sulfide ores. Science 1980, 208, 1417-1424. [CrossRef] [PubMed]

47. Leblanc, M. Platinum group elements and gold in ophiolitic complexes: Distribution and fractionation from mantle to oceanic floor. In Ophiolite Genesis and Evolution of the Oceanic Lithosphere; Peters, T.J., Nicolas, A., Coleman, R.G., Eds.; Ministry of Petroleum and Minerals: Muscat, Oman, 1991; pp. 231-260.

48. Garuti, G.; Fershtater, G.; Bea, F.; Montero, P.; Pushkarev, E.; Zaccarini, F. Platinum group elements as petrological indicators in mafic-ultramafic complexes of the Central and Southern Urals: Preliminary results. Tectonophysics 1997, 276, 181-194. [CrossRef]

49. Brenan, J.M.; Andrews, D. High-Temperature stability of Laurite and Ru-Os-Ir alloy and their role in PGE fractionation in mafic magmas. Can. Mineral. 2001, 39, 341-360. [CrossRef]

50. Garuti, G.; Zaccarini, F. In situ alteration of platinum-group minerals at low temperature: Evidence from serpentinized and weathered chromitite of the Vourinos Complex, Greece. Can. Mineral. 1997, 35, 611-626.

51. Garuti, G.; Zaccarini, F.; Cabella, R.; Fershtater, G.B. Occurrence of unknown Ru-Os-Fe oxide in the chromitites of the Nurali ultramafic complex, southern Urals, Russia. Can. Mineral. 1997, 35, 1431-1440.

52. Zaccarini, F.; Proenza, J.A.; Ortega-Gutierrez, F.; Garuti, G. Platinum Group Minerals in ophiolitic chromitites from Tehuitzingo (Acatlan Complex, Southern Mexico): Implications for postmagmatic modification. Mineral. Petrol. 2005, 84, 147-168. [CrossRef]

53. Zaccarini, F.; Bindi, L.; Garuti, G.; Proenza, J. Ruthenium and magnetite intergrowths from the Loma Peguera chromitite, Dominican Republic, and relevance to the debate over the existance of platinum-group element oxides and hydroxides. Can. Mineral. 2014, 52, 617-624. [CrossRef]

54. McDonald, A.M.; Proenza, J.A.; Zaccarini, F.; Rudashevsky, N.S.; Cabri, L.J.; Stanley, C.J.; Rudashevsky, V.N.; Melgarejo, J.C.; Lewis, J.F.; Longo, F.; et al. Garutiite, (Ni,Fe,Ir) a new hexagonal form of native Ni from Loma Peguera, Dominican Republic. Eur. J. Mineral. 2010, 22, 293-304. [CrossRef]

55. Bonazzi, P.; Bindi, L. Structural and chemical characterization of dienerite, Ni3Ss, and its revalidation as mineralogical species. Can. Mineral.. in press.

56. Hamlyn, P.R.; Keays, R.R. Precious metals in magnesian low-Ti lavas: Implications for metallogenesis and sulfur saturation in primary magmas. Geochim. Cosmochim. Acta 1985, 49, 1797-1811. [CrossRef]

57. Leblanc, M.; Nicolas, A. Ophiolitic chromitites. Int. Geol. Rev. 1992, 34, 653-686. [CrossRef] 